Summary Report

Conversion to Coal in the Industrial Sector

\author{
T. D. Anderson \\ E. C. Fox
}

OAK RIDGE NATIONAL LABORATORY OPERATED BY UNION CARBIDE CORPORATION - FOR THE DEPARTMENT OF ENERGY 


\section{DISCLAIMER}

This report was prepared as an account of work sponsored by an agency of the United States Government. Neither the United States Government nor any agency Thereof, nor any of their employees, makes any warranty, express or implied, or assumes any legal liability or responsibility for the accuracy, completeness, or usefulness of any information, apparatus, product, or process disclosed, or represents that its use would not infringe privately owned rights. Reference herein to any specific commercial product, process, or service by trade name, trademark, manufacturer, or otherwise does not necessarily constitute or imply its endorsement, recommendation, or favoring by the United States Government or any agency thereof. The views and opinions of authors expressed herein do not necessarily state or reflect those of the United States Government or any agency thereof. 


\section{DISCLAIMER}

Portions of this document may be illegible in electronic image products. Images are produced from the best available original document. 
Printed in the United States of America. Available from National Technical Information Service

U.S. Department of Commerce

5285 Port Royal Road, Springfield, Virginia 22161

Price: Printed Copy $\$ 5.25$; Microfiche $\$ 3.00$

This report was prepared as an account of work sponsored by an agency of the United States Government. Neither the United States Government nor any agency thereof, nor any of their employees, contractors, subcontractors, or their employees, makes any warranty, express or implied, nor assumes any legal liability or responsibility for any third party's use or the results of such use of any information, apparatus, product or process disclosed in this report, nor represents that its use by such third party would not-infringe privately owned rights. 
Contract No. W-7405-eng-26

Engineering Technology Division

SUMMARY REPORT
CONVERSION TO COAL IN THE INDUSTRIAL SECTOR

T. D. Anderson E. C. Fox

Manuscript Completed - December 20, 1978

Date Published - JANUARY, 1979

Prepared by the

OAK RIDGE NATIONAL LABORATORY

Oak Ridge, Tennessee 37830

operated by

UNION CARBIDE CORPORATION

for the

DEPARTMENT OF ENERGY 
THIS PAGE

\section{WAS INTENTIONALLY \\ LEFT BLANK}


ACKNOWLEDGMENTS $\ldots \ldots \ldots \ldots \ldots \ldots \ldots \ldots \ldots \ldots \ldots \ldots \ldots \ldots \ldots \ldots \ldots \ldots \ldots \ldots$

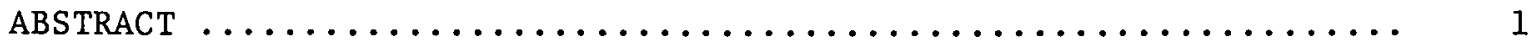

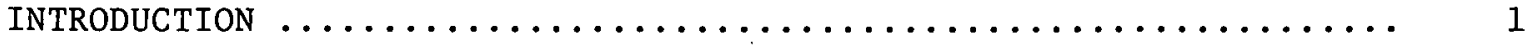

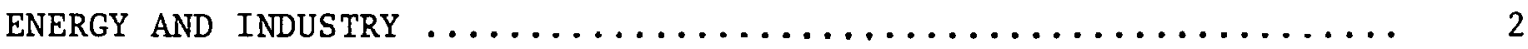

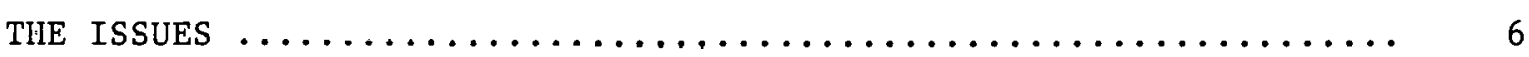

Availability of Coal and Combustion Equipment $\ldots \ldots \ldots \ldots \ldots \ldots . \ldots$

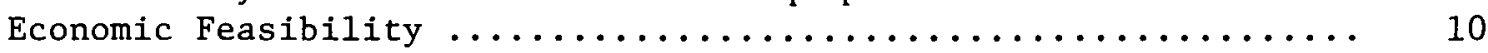

Allocation of Capital Resources and Other Strategic Planning

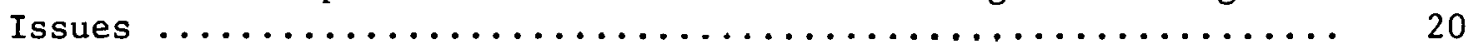

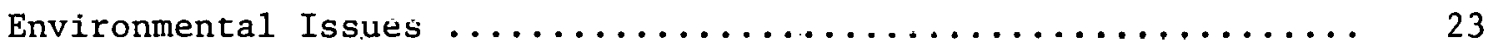

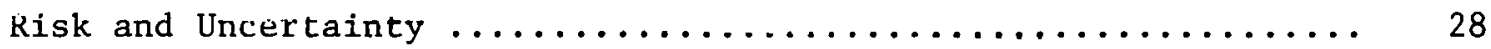

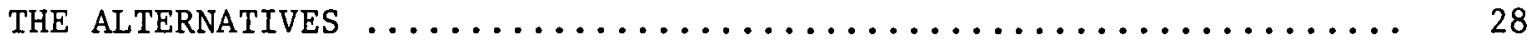

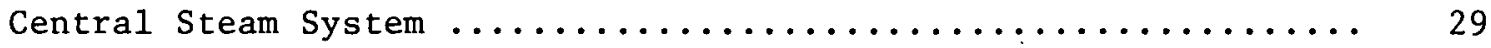

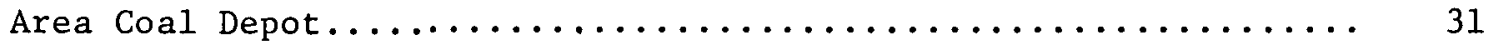

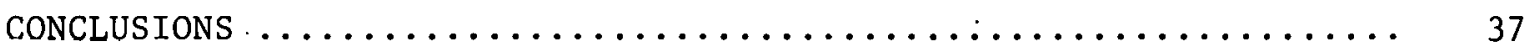

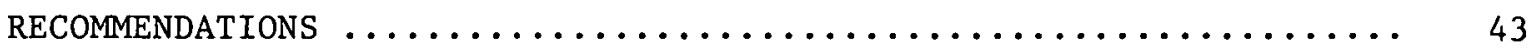

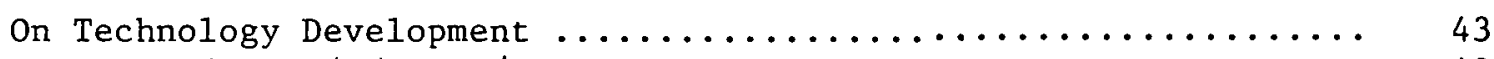

On a Coordinated Energy/Environmental Pulicy ............. 43

On Industry/Government Cooperation $\ldots \ldots \ldots \ldots \ldots \ldots \ldots \ldots \ldots \ldots . \ldots \ldots$

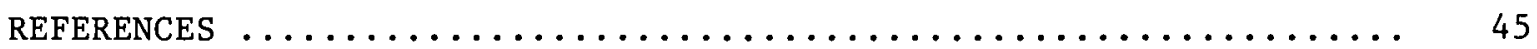




\section{THIS PAGE \\ WAS INTENTIONALLY \\ LEFT BLANK}




\section{ACKNOWLEDGMENTS}

The authors gratefully acknowledge the contributions of Car1 Di Bella of the Department of Energy/Fossil Energy Program, who provided guidance and assistance in conducting the work. We are also indebted to the many representatives of industry and commerce who contributed valuable time and information. Special thanks are in order to the following for their review and constructive critique of the draft manuscript:

R. L. Aspenson - 3M Company

J. T. Cockburn - Celanese Chemical Company

L. R. Green - Sears, Roebuck and Company

E. R. Moats - Goodyear Tire and Rubber Company

P. L. Tremont - Monsanto Company

R. L. Wright - Union Carbide Corporation

In making these acknowledgments, however, we wish in no way to shift the burden of responsibility to others; the conclusions and recommendations are strictly Lhose of the authors. 
THIS PAGE

\section{WAS INTENTIONALLY \\ LEFT BLANK}




\title{
SUMMARY REPORT \\ CONVERSION TO COAL IN THE INDUSTRIAL SECTOR
}

T. D. Anderson E. C. Fox

\begin{abstract}
A key element of the National Energy Plan is the conversion of Industrial boiler fuels from natural gas and oil to coal. But widespread conversion to coal is not taking place in the industrial sector. This study identifies the important factors that restrict the acceptance of coal in industry and examines some alternatives to conventional on-site combustion. An analysis of the economic and environmental barriers is made along with a discussion of financial and logistical constraints. The results indicate that the 1ark of substantial economic incentives, increased risks due to intensified capital requirements, and the absence of a clear environmental policy make coal a poor choice for most of industry. The proposed tax provisions of the National Energy Plan would improve the economic incentives to convert to coal, but for most industrial energy users the incentives will still be too small and the risks too large. Alternatives to conventional on-site facilities considered are central community steam generation and an area coal terminal. These concepts appear promising for some regions of the country.
\end{abstract}

\section{INTRODUCTION}

The National Energy Plan l (NEP) sets as a national goal the conversion of industrial steam generation from oil and gas to coal. The proposal sets forth tax provisions intended to speed the conversion process. In addition, the Department of Energy (DOE) is committed to an extensive research and development program to provide technology for the environmentally acceptable, efficient, and economic combustion of coal. Nevertheless, these advanced technologies alone may not be sufficient to overcome the barriers to the wide acceptance of coal as an industrial fuel. For the majority of American industry, coal is an unfamiliar form of energy, and the 1ssues involved in converting to coal are far more complex than those involved in simply buying another gas- or oil-fired boiler.

The purpose of this study is to identify and quantify the important factors that restrict the conversion of industrial steam generation to direct coal combustion and to evaluate potential technical and 
institutional alternatives that may improve the prospects for using coal in industry. This report summarizes the results of the study; reference should be made to the main report ${ }^{2}$ for detailed information.

The time-frame for the study is the period through 1985. Thus, nearterm issues and technical options were emphasized. Coal combustion technologies that were examined are:

1. Conventional stoker and pulverized coal boilers with and without stack gas scrubbers.

2. Atmospheric fluidized bed boilers.

3. Coal-oil mixture as a retrofit fuel for existing oil- or gasfired boilers.

Installation sizes up to one million pounds per hour of steaming capacity were considered; this size range includes over $75 \%$ of the industrial steam generation in the United States.

\section{ENERGY AND INDUSTRY}

As illustrated in Fig. 1, industry is the major energy consuming sector in the United States; it accounts for nearly $40 \%$ of our total primary energy input. In addition, industry is the leading user of natural gas (Fig. 2). Although industrial fuels are used in a variety of ways, including direct process heating and as chemical feedstocks, steam raising is the single largest application (Fig. 3). Furthermore, because the use of coal as a feedstock or for direct process heating is limited, the replacement of natural gas and oil as a boiler fuel is technically the easiest goal in the near term. This is the reason for the emphasis on boiler fuels in the National Energy Plan.

The major potential market for coal-fired industrial boilers is in units that are small relative to those used by electric utilities. As shown in Fig. 4, boiler installations of one million pounds per hour of steam or less include over $75 \%$ of the industrial steam capacity in the U.S. Generally, an installation will consist of several units. In contrast, a typical coal-fired electric power plant will have a steaming capacity of 8 to 9 million pounds per hour. 
ORNL-DWG 78-16935

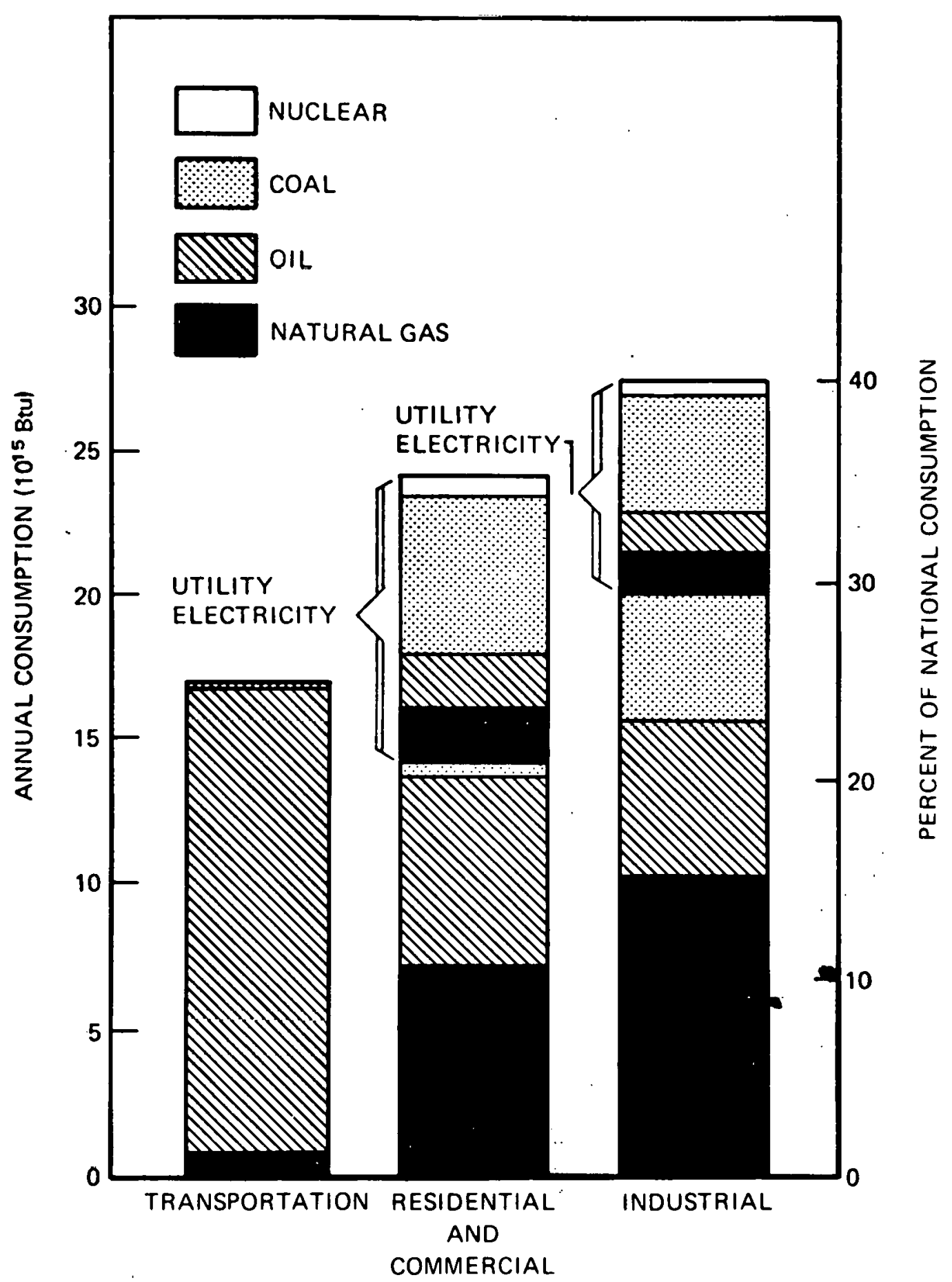

Fig. 1. Use of energy by consuming sector (Ref. 3). 


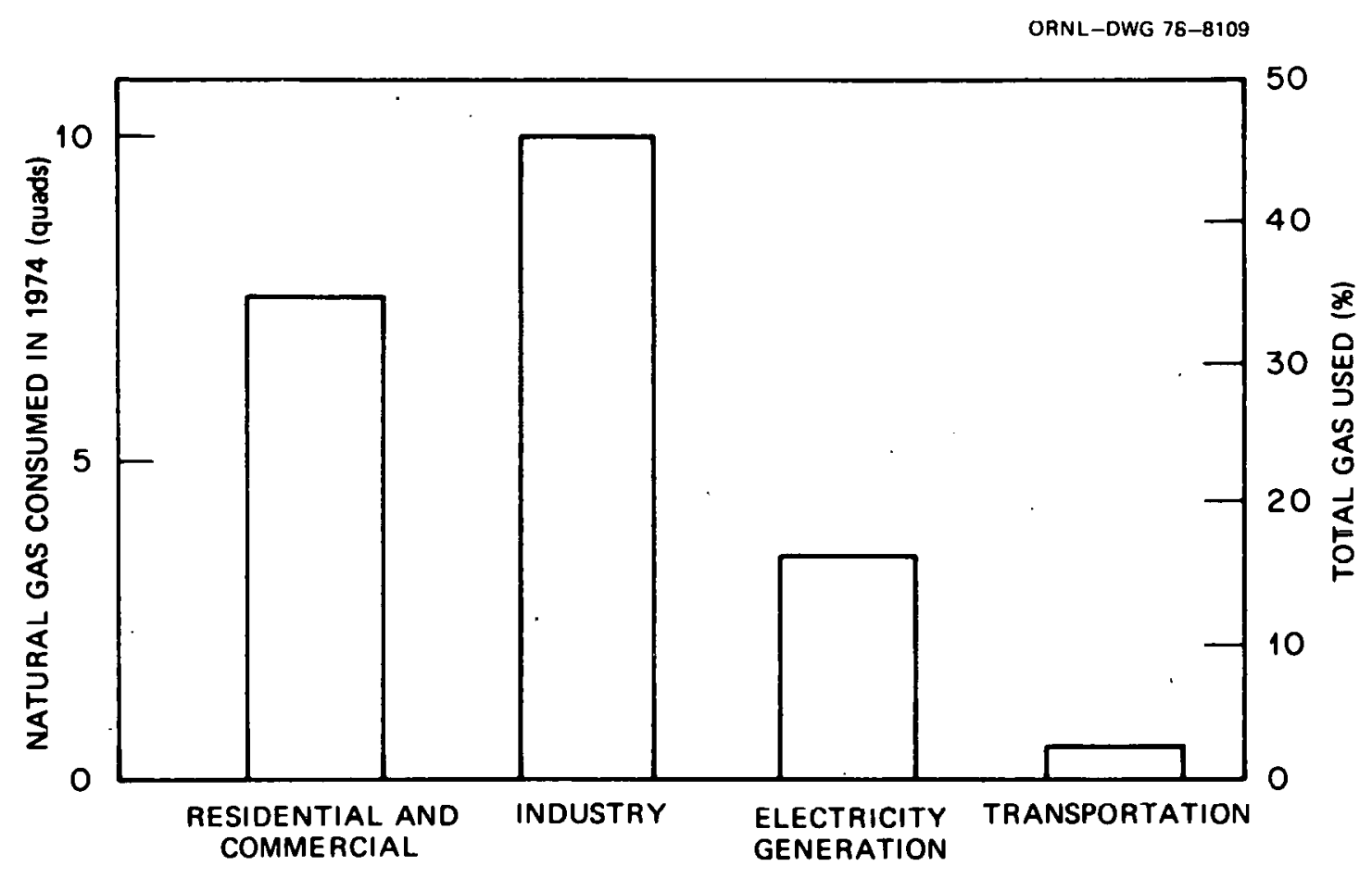

Fig. 2. Natural gas consumption in the U.S. (Ref. 3).

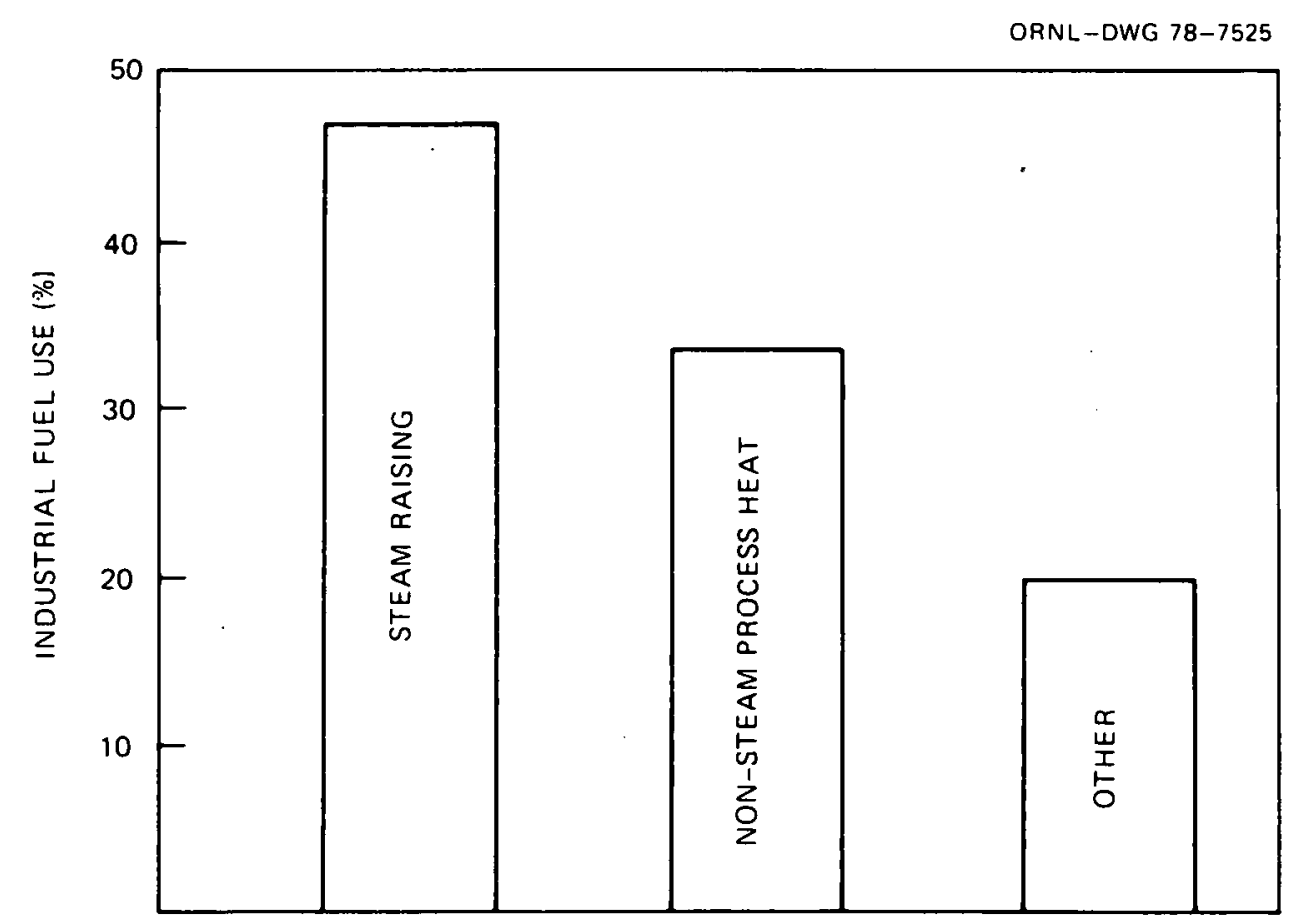

Fig. 3. Industrial fuel use (Ref. 4). 


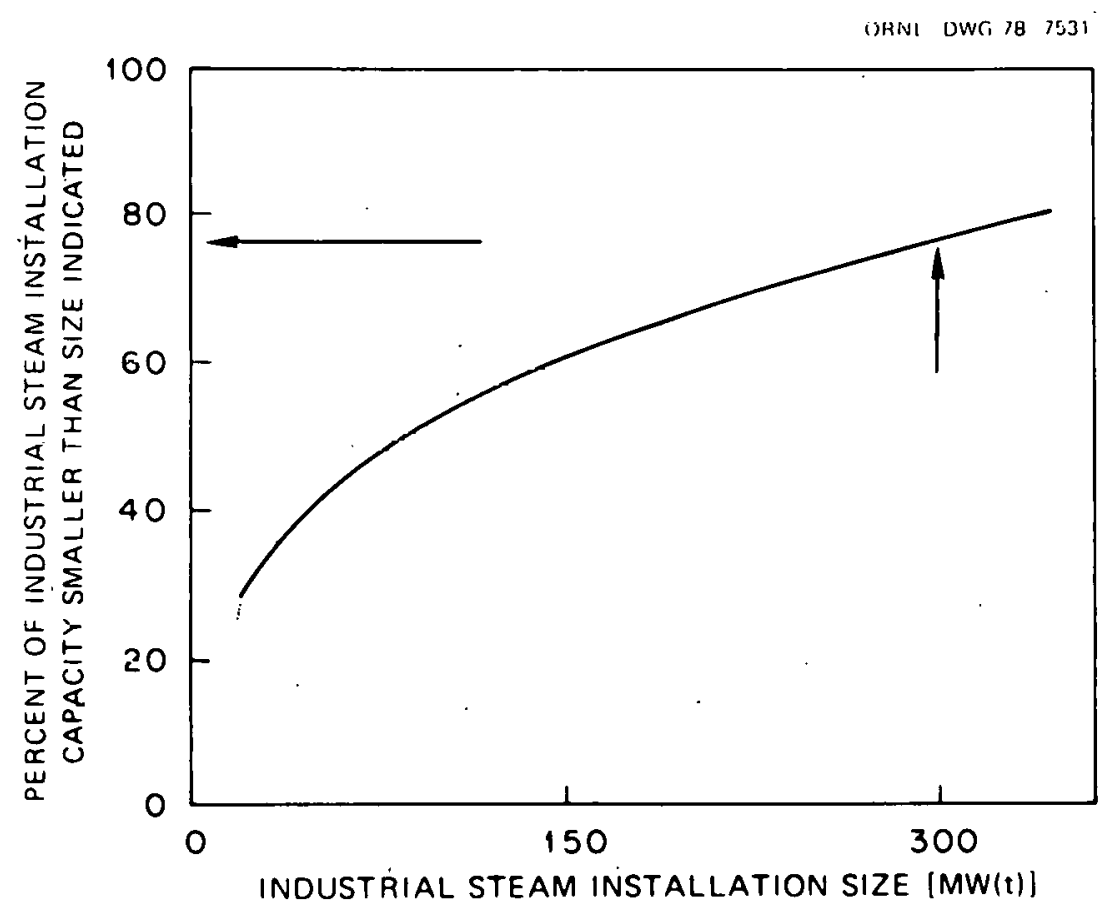

Fig. 4. Industrial steam market as a function of total installation steam demand (Ref. 5).

Considering the size of the market and the present makeup of fuels, it is clear that the industrial sector is a prime target if the goal is to substitute coal for premium fuels. But the decision to convert to coal is largely in the hands of the industrial energy user. For example, there are no regulations that would force an industrial energy user, who is presently burning gas or oil and does not have coal burning capabilicles, to convert to coal. Both present regulations and the proposed NEP legislation relate primarily to new installations. A user might wish to build a new installation either to replace existing oil- or gas-fired boiler capacity or to expand capacity. As illustrated in Fig. 5, the major opportunity for increasing the use of coal is in replacing existing oiland gas-fired capacity. One implication of this is that the market potential for industrial coal is relatively insensitive to the growth rate of industrial energy demand. But a more important implication is that the conversion to coal will take place only if coal has merits relative to 
ORNL-DWG 78-7521

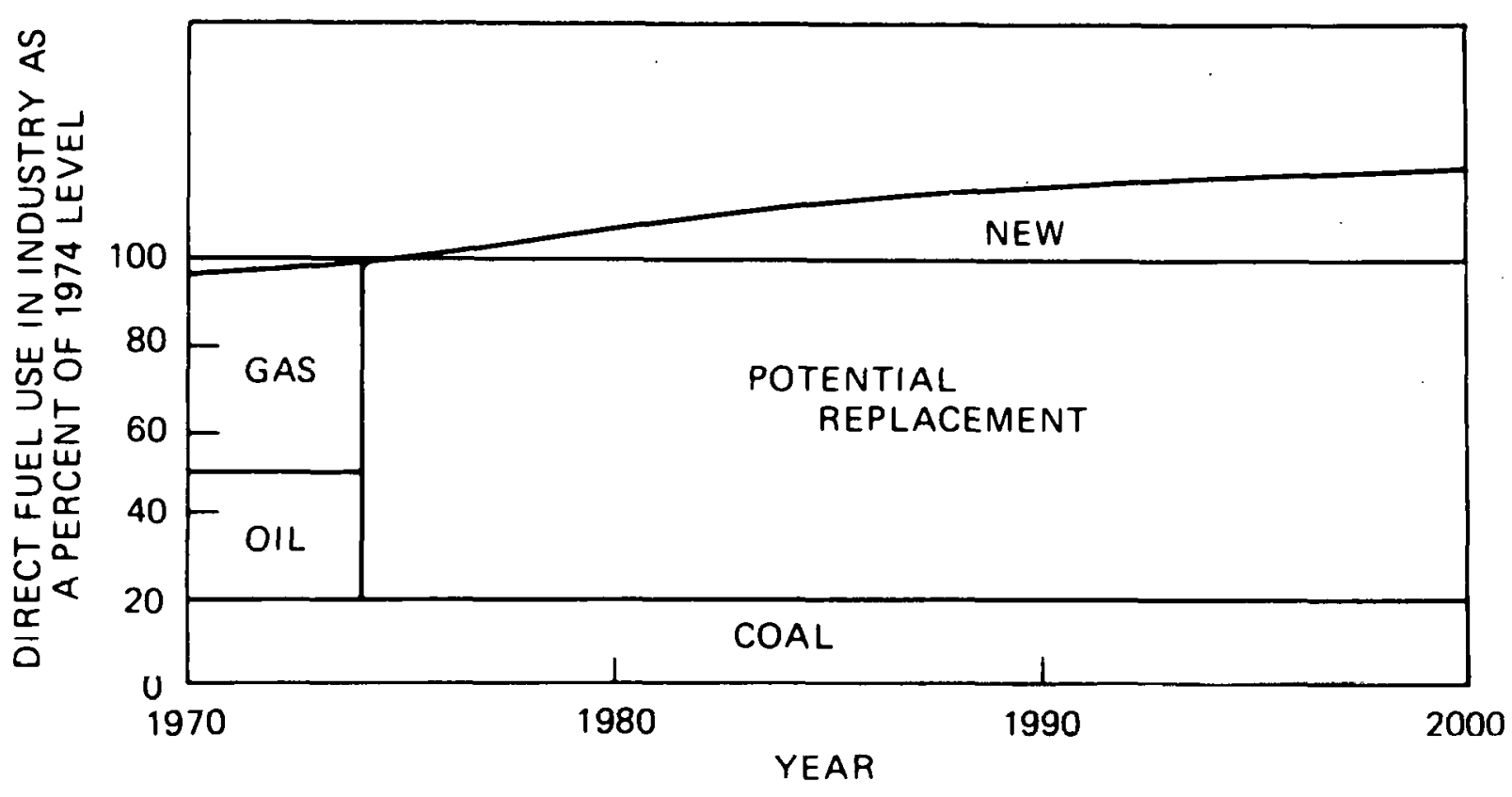

Fig. 5. Industrial market potential for coal (Ref. 3).

alternatives as judged by the user. Since the major market is in replacement - not in expansion - and replacement of existing oil and gas equipment by coal is not generally covered by government mandate, the potential user has some options. And one option is to continue to use existing equipment and fuels; in general, this is what is happening at the present time.

\section{THE ISSUES}

As suggested previously, the conversion of industrial boiler fuels from gas and oil to coal involves a number of complex issues. Although most people believe that conversion to coal would be of significant national benefit, mere belief will not make it happen. The actual implementation will come about only as a cumulative result of hundreds of individual decisions in the industrial. sector. This section summarizes 
the analyses of the issues involved in the potential industrial user's decision making process. The issues were identified through discussions with industrial energy users, railroads and barge lines, equipment suppliers, State and Federal Agencies, and coal suppliers. Although the survey of various groups was not comprehensive, the viewpoints are believed to be representative.

\section{Availability of Coal, and Combustion Equipment}

One of the first questions that a potential user needs to ask is whether the conversion to coal can be physically carried out. Can proven combustion equipment be obtained on a commercial basis and on a reasonable schedule? Can coal be purchased and is there a means of getting it delivered? In mid-1977, the answers to these questions are all yes for most potential coal users.

\section{Combustion equipment}

The direct combustion of coal is neither a new nor undeveloped technology. Coal-fired boilers have been common in industry for over a century. Conventional pulverized-coal and stoker-fired boilers are commercially available from several U.S. manufacturers. Stoker-fired boilers can be supplied in sizes ranging from small residential units to industial units capable of generating up to $400,000 \mathrm{lb} / \mathrm{hr}$ of steam. These units can accommodate coal types from anthracite to lignite and peat, depending on the design of the furnace and the stoker system. Pulverized coal-fired boilers are available in sizes from $175,000 \mathrm{lb} / \mathrm{hr}$ of steam for industria1 units to 10 million $1 \mathrm{~b} / \mathrm{hr}$ of steam for central station power plants. The lower limitation on pulverized coal boiler size has, in the past, been one of economics.

Conventional combustion technologies coupled with low sulfur coal or one of several types of scrubbers can meet the present emission standards for new sources. Several different stack gas scrubbing systems are being developed but, for the time frame considered in this study, only the lime/ limestone and the double alkali systems were considered to be sufficiently developed for commercial consideration. In early 1978, 34 flue gas 
desulfurization systems were in operation in industry; 20 of these were double alkali type systems. ${ }^{6}$ Even though the number of scrubber installations in industry is significant, many industrial energy users remain skeptical of flue gas desulfurization as a practical choice. Operability of the equipment is the issue. The acceptability of scrubbers is likely to improve with time as more experience is gained.

Developmental technologies that could become commercial by 1985 are atmospheric fluidized bed boilers and coal-oil mixtures. Fluidized bed boilers have the potential for meeting present and future emissions standards more economlcally than conventional coal-fired boilers. Another advantage, especially for industrial applications, is their flexibility in accepting a wide range of fuels. Because of their potential advantages, fluidized bed boilers are being developed in the U.S. and elsewhere. There are numerous experimental projects, one $30 \mathrm{MW}(\mathrm{e})$ pilot plant, and plans for several demonstration units. At least six of the demonstration projects are classified as industria1. However, moet of these produce luw pressure steam and will be operated in environments that are nonrepresentative as far as much of industry is concerned. Most industrial energy users do not consider fluidized bed boilers to be a commercial option even though the potential advantages are recognized. Extensive demonstration of the concept under typical industrial conditions will be required before industrial acceptance is achieved.

The use of coal-oil mixtures is being investigated as a means of retrofitting existing equipment originally designed to burn oil or gas. Tests sponsored by DOE and the Electric Power Research Institute (EPRI) have shown some promising results, but there are several technical questions that must be resolved before this concept could be appli,ied on a broad scale. The main report (Ref. 2) presents some of these questions and a brief economic analysis.

In sum, there are some new technologies that could become important by 1985 , but conventional boilers are viewed as the only choice by most of industry. Such boilers are readily obtainable commercially and, as a matter of fact, industrial boiler production is well below production capacity. Whether this situation will continue, and for how 1ong, depends on the degree of success of the Federal government's program to get 
industry to convert. Although coal boilers can be manufactured in the same facilities as oil and gas boilers, the manufacturing capacity (1b/hr of boiler capacity per year) is considerably reduced if coal-fired boilers are to be produced. Obviously, if a large portion of industry attempts to convert at the same time, manufacturing capability will become a problem. Furthermore, boilermakers are not likely to expand their capacity dramatically because after industrial conversion is complete, the boiler manufacturers would be left with a large excess of capacity.

Since coal-fired industrial boilers can presently (mid-1977) be obtained on a good schedule, some industrial steam users believe this is an important fartor in favor of acting now. If conversion to coal is inevitable, and if the future demand for new boilers becomes high, then conversion now can be accomplished in less time and at a lower price.

$\underline{\text { Coal and its delivery }}$

Although there is little question about the present availability of coal, potential industrial coal users believe the coal supply question is one of the most important considerations. For the large user ( $o$ one-half million tons per year and up, equivalent to $1.5-2 \times 10^{6} \mathrm{lb} / \mathrm{hr}$ steam), long-term coal contracts are feasible because the coal supplier can use such contracts as the justification for financing the opening of new mines. For the small user, long-term contracts are much more difficult to find, but possible if a coal company has excess capacity. Additionally, the small user will be less able to secure multiple contracts to ensure a coal supply in the event of a mine workers' strike or a failure in the transportation system. Thus, small users may need to rely on spot purchases with attendant uncertainties about prices and availability.

The question of transportation to most potential coal users relates to railroads. Most rail operators are of the opinion that coal transportation will not be the limiting factor in increasing the use of coal. Certainly, Lle Lransportation qucotion is not a major one at the present time; but coal transportation presents a set of rather new logistical questions to most industrial steam users that have been using oil or gas. Railroads are regulated public carriers and, as such, cannot sign contracts. Thus, there is no contras.t that can be used to obtain financing for new 
coal cars. The purchase of coal cars to supply a new customer involves a certain amount of risk on the part of the railroad. As a consequence, many coal customers find it economically advantageous to purchase their own cars. Although large companies will not hesitate to purchase this sort of equipment, some smaller companies will be reluctant to move into areas not directly related to their primary products.

\section{Economic Feasibility}

Without provisions of the National Energy Plan

There are many constraints, both internally and externally imposed, on a firm's decision-making process; but within these constraints the single most important determinant relative to conversion to coal is economic feasibility. In other words, is coal a good economic choice relative to the alternatives? In general, industrial users ran sonsider only a few alternatives as their major fuel source. These are: natural gas, oil, coal, wood and by-product wastes. Wood and by-product wastes are generally restricted to very specialized industrial applications and have not been considered.

For a majority of oil- and gas-burning industries, the present steam raising equipment is not sllitah1e for burning coal. Thus, Lhe cual opeton is not a simple matter of switching fuels - it is to build new steam facilities. Generally, the alternative to coal is to continue to burn gas or oil along with implementing conservation measures. The economic test that coal must pass is that the increased investment is offset by lower operating costs.

For the analysis, natural gas is assumed to reach the world market price of oil and not be available for industries who are considering direct coal combustion. It is apparent that the true competition for coal, at least in the near term, is oil and it was in this light that the engineering economic analysis was conducted.

There are two questions that must be answered in order to demonstrate the economic feasibility of switching to direct coal combustion over the alternatives. First, what is it worth, and second, what does it cost? 
One of the easiest ways to do this is to compare the annual costs of a coal facility to those of an oil plant to determine what is the maximum price that can be paid for coal to ensure that there is enough savings over oil to pay for the added investment. Then, this can be compared to the anticipated delivered cost of coal to determine if it is a viable option.

If an industrial facility is presently firing oil and is considering building a new coal-fired plant, then the operation and annualized capital costs for the new coal plant must be less than or equal to the cost of operating the oil-fired plant if it is to be an attractive option. By knowing the rapital investment required for the coal plant, the nonfuel operating and maintenance cost and the operating cost of an oil-fired plant, the price that can be afforded for coal at the start of the project can be calculated.

For this analysis the ground rules listed in Table 1 were used. Coal, oil, and nonfuel operating costs were assumed to escalate at $7 \%$ per year over the lifetime of the plant. The return on investment of $15 \%$ was also used to discount future costs.

Table 1. Economic analysis ground rules

\begin{tabular}{ll}
\hline Plant lifetime & 20 years \\
Debt to equity ratio & 0. \\
Federal income tax rate & $48 \%$ \\
State income tax rate & $3 \%$ \\
Property tax rate & $2 \%$ \\
Investment tax credit & $10 \%$ \\
Return on investment (after tax) & $15 \%$ \\
Escalation of operating costs & $7 \%$ \\
Year of dollars & 1977 mid-year \\
Operating rate & $85 \%$ \\
\hline
\end{tabular}


To evaluate the economic feasibility of coal-fired boilers, they must not only be compared with the alternatives, but this comparison must also be conducted at specific sites to account for the regional variations in costs of coal and transportation. For this purpose, seven cities were chosen as representatives of the major industrial regions of the country: Chicago, Houston-Galveston, Knoxville, Minneapolis-St. Paul, New Orleans-Baton Rouge, Los Angeles, and Philadelphia. For each of these areas, the affordable cost of coal at the project start was calculated for three separate combustion systems; stoker and pulverized-coal-fired boilers to burn low sulfur coal, stoker and pulverized-coal-fired boilers with flue gas desulfurization, and atmospheric fluidized bed combustion systems to burn high sulfur coal. Additionally, four plant sizes were considered: $100,000 \mathrm{Ib} / \mathrm{hr}$ steam; $250,000 \mathrm{lb} / \mathrm{hr}$ steam; $500,000 \mathrm{lb} / \mathrm{hr}$ steam; and 1,000,000 1b/hr steam. Then the breakeven costs werc compared to costs of delivered coal from mines which would be typical sources for that reginn.

The delivered costs of coal were calculated using mine mouth prices derived from Ref. 7 which are listed in Table 2, and from rail tariffs obtained through numerous railroad companies. The costs for the plants considered in this analysis were adjusted to include coal handling facilities that were commensurate with the size of the train shipments. For the small size plants, the tradeoff between unloading facility and transportation cost was adjusted to optimize the cost differences. It was further assumed that the small plants $\leq 250,000 \mathrm{lb} / \mathrm{hr}$ would pay spot prices and those $\geq 500,000 \mathrm{lb} / \mathrm{hr}$ would get contract rates.

These comparisons are presented in Figs. 6-11 for Chicago and Houston and in Tables 3-4 (see Ref. 2 for details) for other regions. Although specific sites indicate differences in the economic incentives, there are some general conclusions that can be drawn. The cost that can be afforded for coal increases as the size of the steam installation increases. This is because the cost of equipment for larger coal steam plants is less per unit of output than a smaller size plant. Also, since the number of operators does not increase substantially for larger size units, the cost of operation per unit of output is also less. Further, the cost of delivered coal decreases as the steam demand 
Table 2. Reference mine mouth coal prices

\begin{tabular}{lccccc}
\hline \multicolumn{1}{c}{ Region } & $\begin{array}{c}\text { HHV } \\
(\text { Btu/1b) }\end{array}$ & $\begin{array}{c}\text { Sulfur } \\
(\%)\end{array}$ & $\begin{array}{c}\text { Ash } \\
(\%)\end{array}$ & $\begin{array}{c}\text { Contract price } \\
(\$ / \text { ton })\end{array}$ & $\begin{array}{c}\text { Spot price } \\
(\$ / \text { ton })\end{array}$ \\
\hline Southeast West Virginia & 12,000 & 0.8 & 14 & $22.50-25.00$ & $26.50-28.50$ \\
Illinois & 11,000 & 2.9 & 11 & $18.00-19.00$ & $20.00-23.25$ \\
Tennessee & 11,800 & 1.4 & 14 & $22.00-24.00$ & $23.00-25.00$ \\
South Wyoming & 10,500 & 0.6 & 8.5 & $14.50-15.50$ & 15.00 \\
Utah & 10,800 & 0.6 & 10 & $17.00-17.50$ & 17.00 \\
Montana & 8,750 & 0.7 & 8 & $7.50-8.75$ & 7.75 \\
West Pennsylvania & 11,700 & 2.4 & 15.3 & $17.75-18.00$ & 17.75 \\
\hline
\end{tabular}




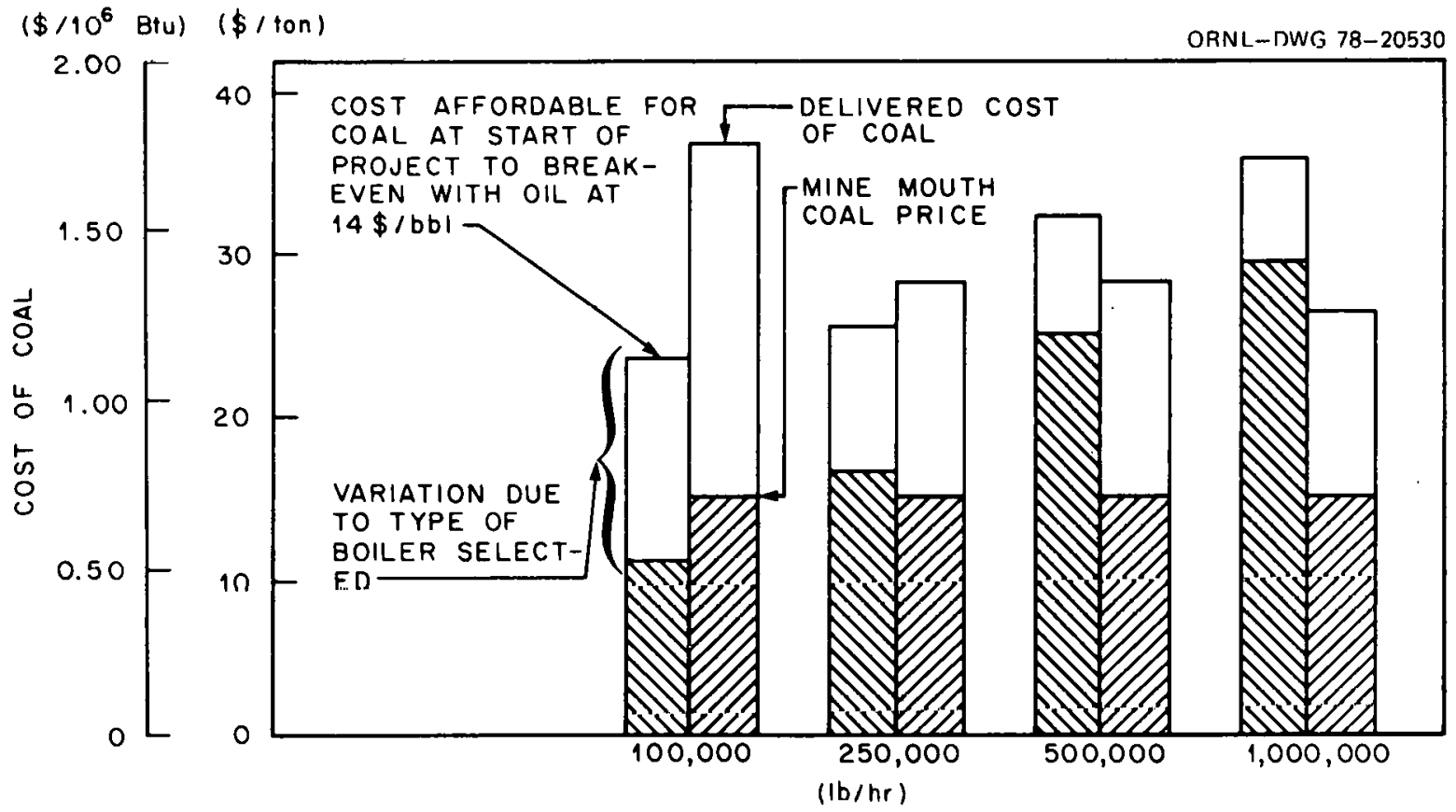

Fig. 6. Comparison of break-even and delivered cost of coal for low-sulfur Wyoming coal burned in industrial boilers in Chicago.

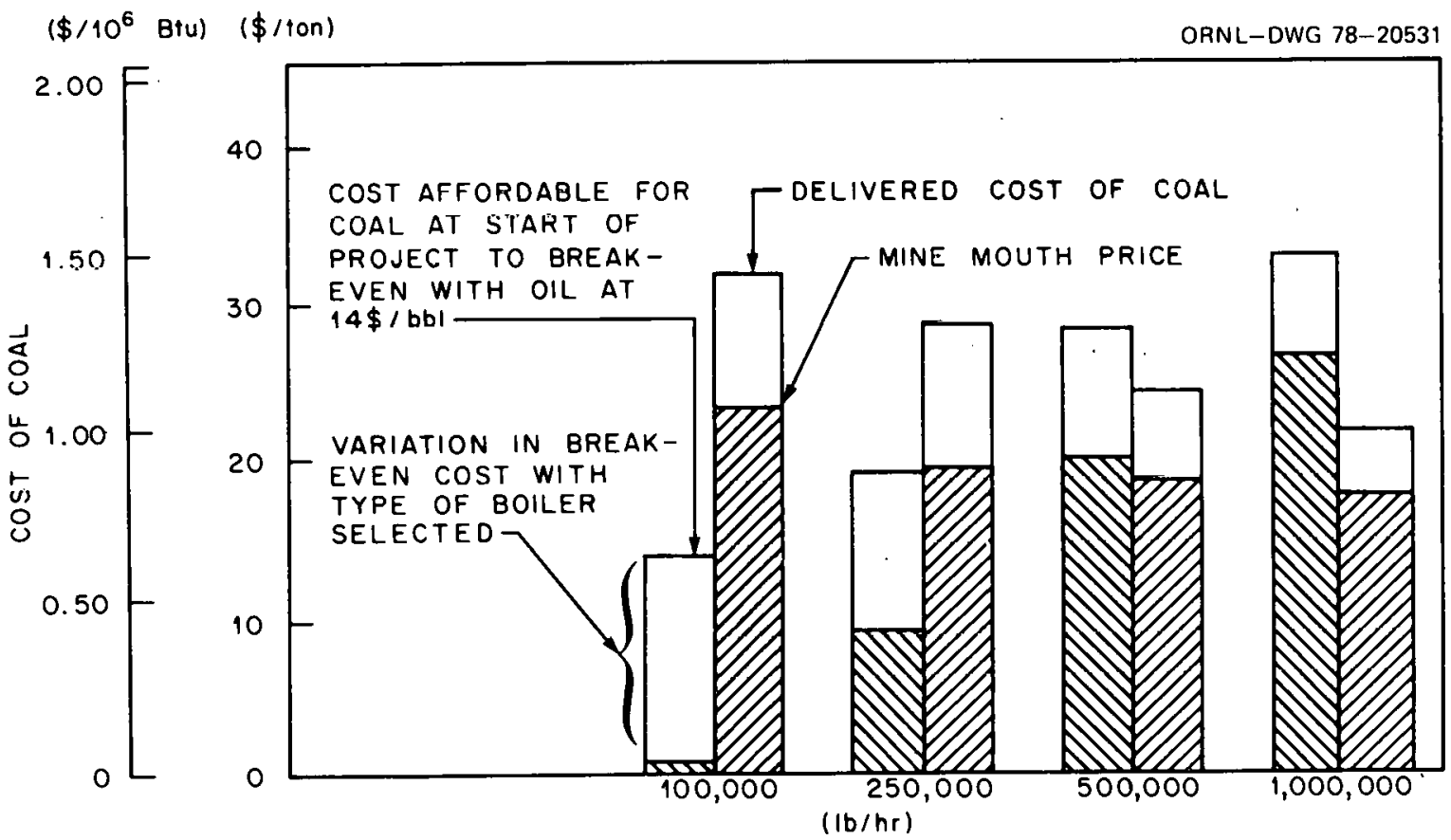

Fig. 7. Comparison of break-even and delivered cost of high sulfur Illinois coal burned in industrial boilers with flue gas desulfurization in Chicago. 


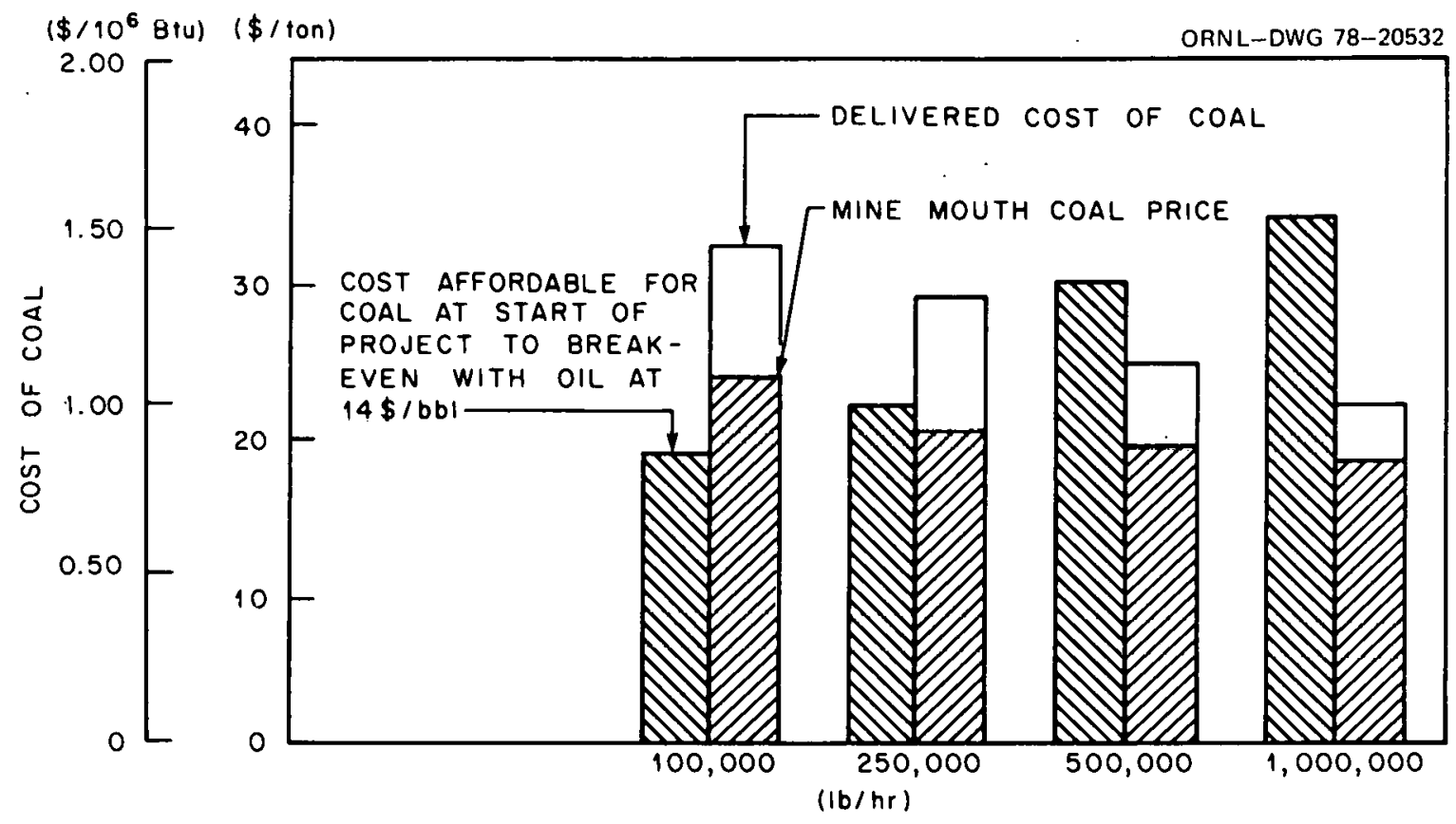

Fig. 8. Comparison of break-even and delivered cost of coal for high sulfur Illinois coal burned in industrial fluidized bed boilers in Chicago.

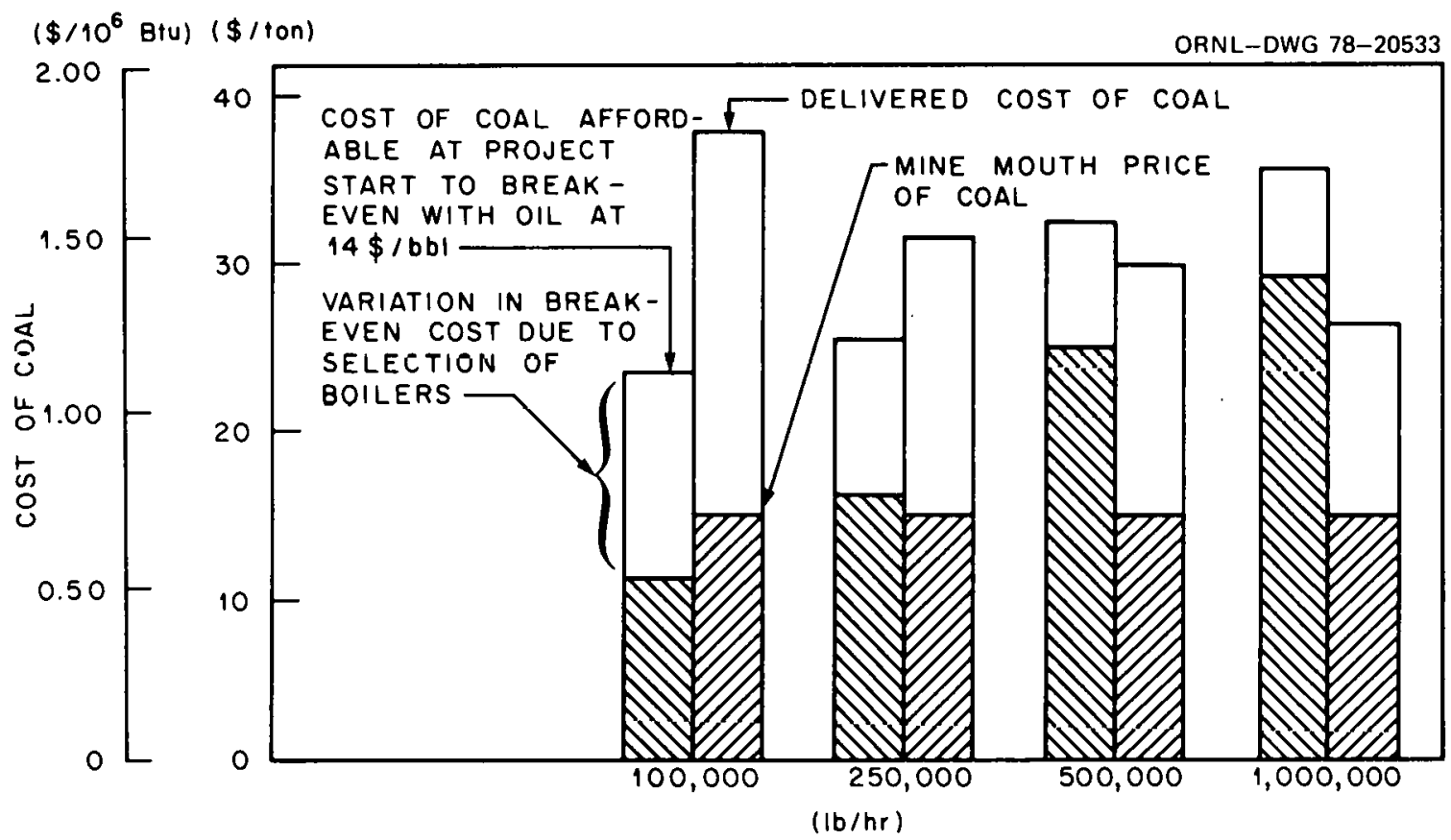

Fig. 9. Comparison of break-even and delivered cost of low sulfur Wyoming coal burned in industrial boilers in Houston. 


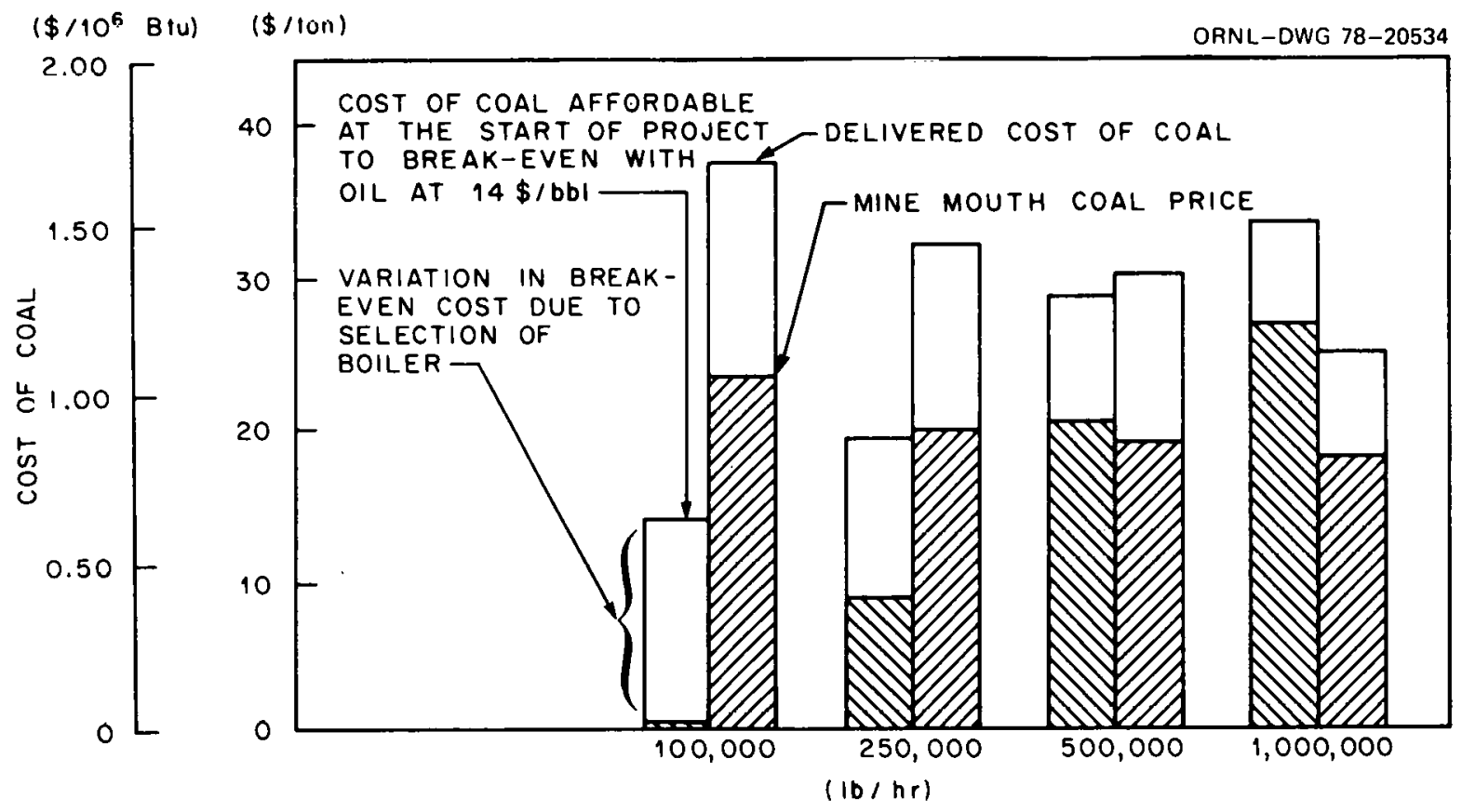

Fig. 10. Comparison of break-even and delivered cost of high sulfur Illinois coal burned in industrial boilers with flue gas desulfurization in Houston.

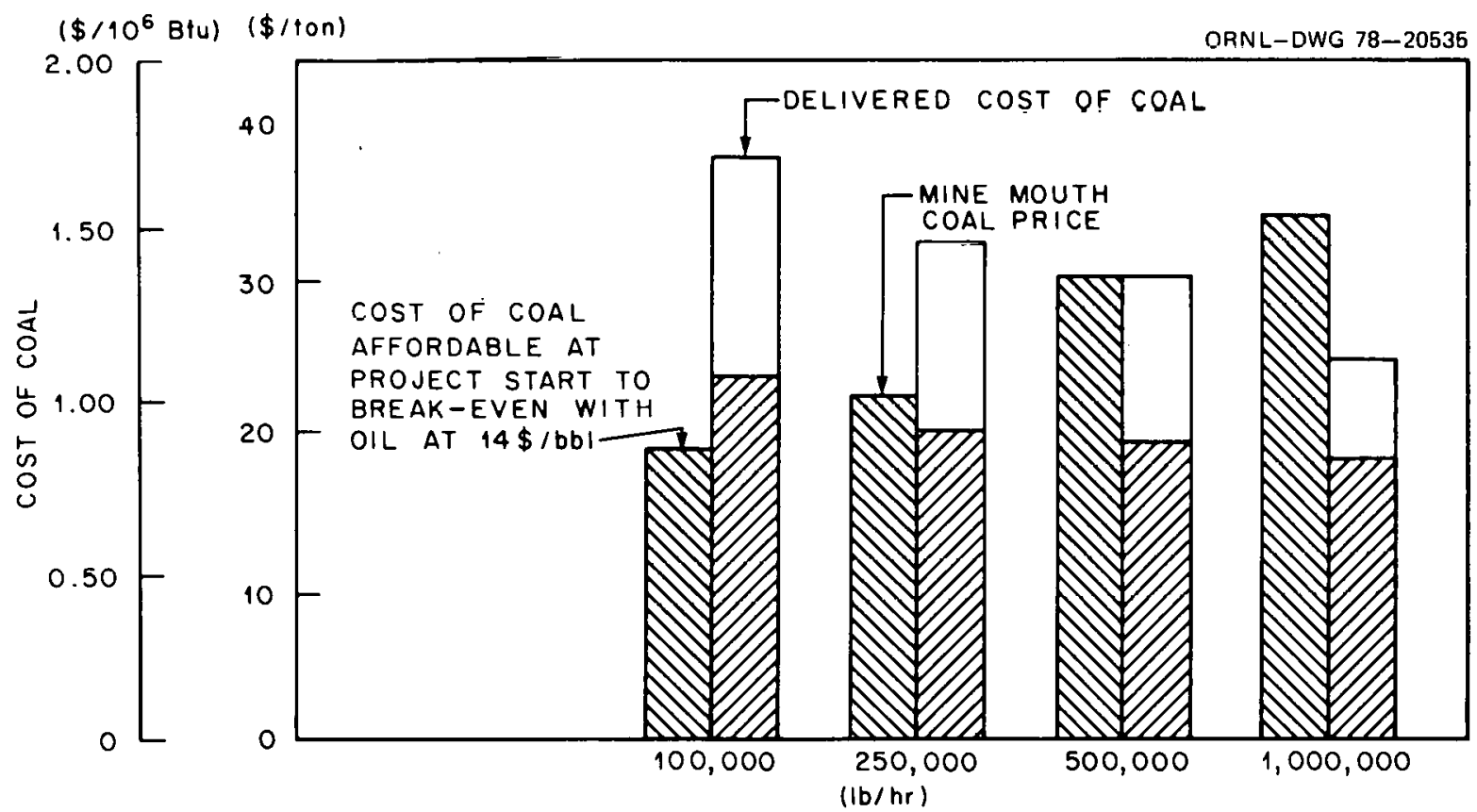

Fig. 11. Comparison of break-even and delivered cost of high sulfur Illinois coal burned in industrial fluidized bed boilers in Houston. 
Fable 3. Break-even and delivered cost of coal for industrial boilers in Houston

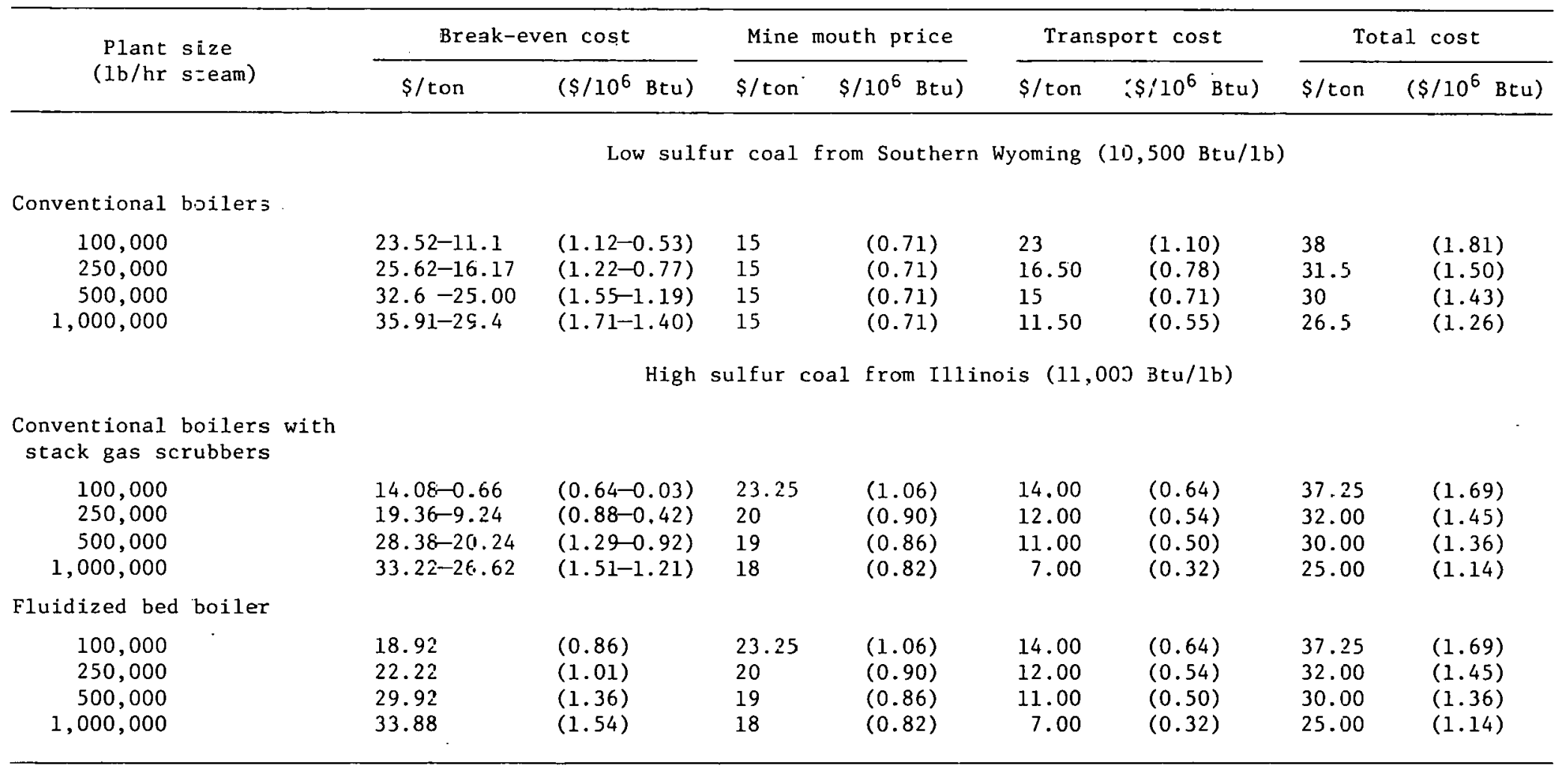


Table 4. Break-even and delivered cost of coal for industrial boilers in Chicago

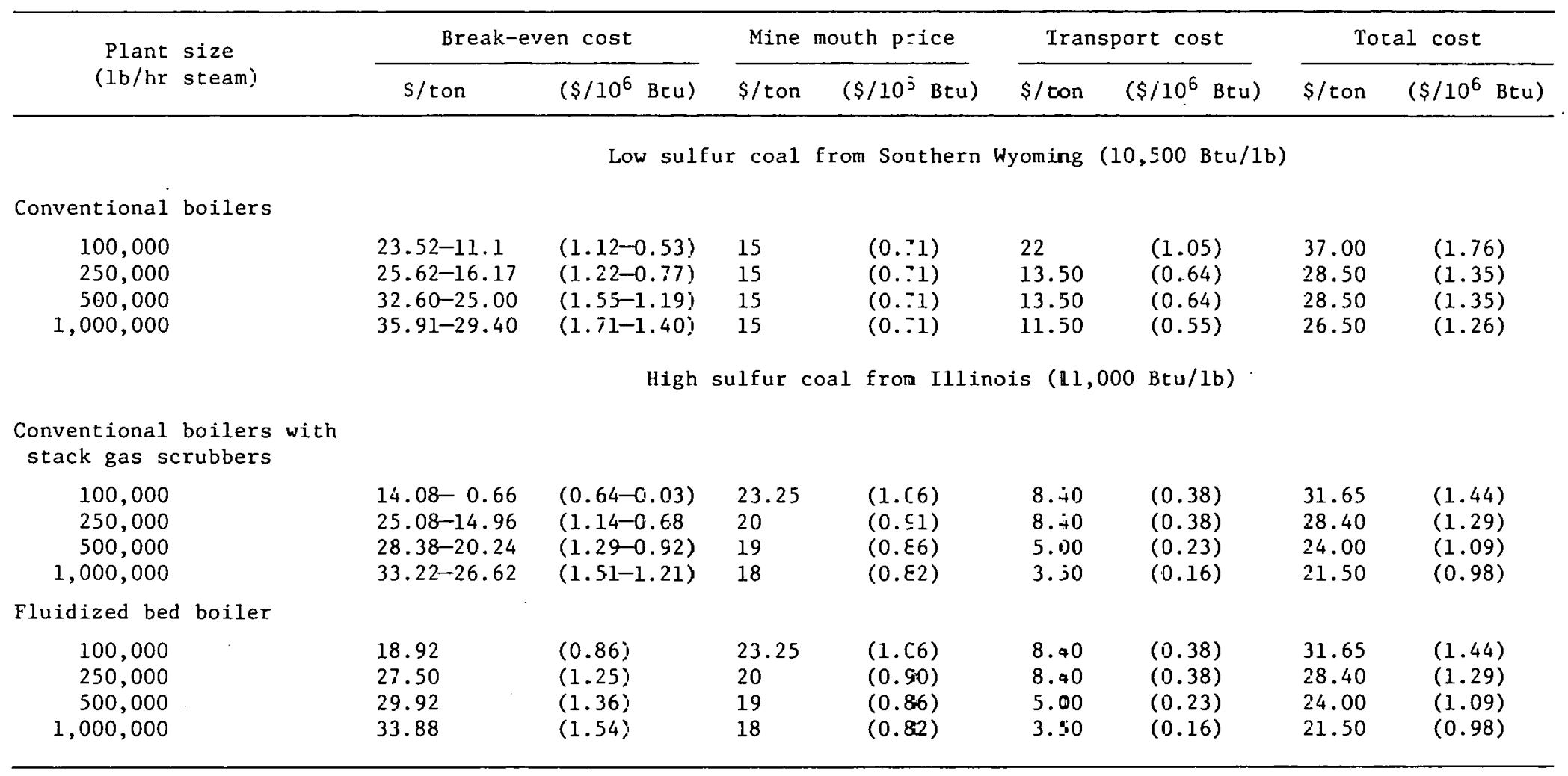


increases, which also makes the comparison between allowable and delivered cost more attractive as the plant size becomes larger. The decrease in delivered coal costs can come from two advantages that a larger user has. First, because of the larger coal demand, it is possible to secure a more favorable contract; secondly, larger train and barge shipments are much cheaper than single cars, especially for long distances.

As a result, in every area considered, the economic incentives to convert an industrial steam installation from oil or gas to coal improve with larger installations and is less attractive for smaller ones. In general, an industrial installation that has a steam load greater than $1,000,000 \mathrm{lb} / \mathrm{hr}$ could justify converting to direct coal combustion based on the economic incentives. However, for most plants, which use less than $500,000 \mathrm{lb} / \mathrm{hr}$ of steam, there is an economic disincentive to switch to coal. For sizes between $500,000-1,000,000 \mathrm{lb} / \mathrm{hr}$, the incentives vary from region to region, but for sizes much below $1,000,0001 \mathrm{~b} / \mathrm{hr}$, the incentives are too small to give coal serious consideration. It can be seen from Fig. 4 that, regardless of other factors, about $70 \%$ of industry would not choose coal simply based on the lack of any economic incentive to do so.

This analysis also indicates that burning a high sulfur coal with scrubbers in an area such as Chicago, which is near high sulfur coal fields, is more attractive than it would be in Houston, which is significantly farther from the mine. However, the option of burning a.lowsulfur wectern coal without scrubbers is at least as good or better in both locations. This relationship was similar in every region considered and indicates that requiring new coal sources, such as industrial boilers, to use scrubbers regardless of the sulfur content of the coal will decrease the incentives to shift to coal.

Aside from the fact that the atmospheric fluidized bed boiler is not a demonstrated commercial technolngy, the economic analysis indicates it would improve the incentives to convert to coal. For areas near highsulfur coals (Chicago, Philadelphia, Knoxville) the improvement would be significant. For areas near low-sulfur coal (Los Angeles, Minneapolis) 
burning coal without scrubbers in conventional equipment would still be a better option.

\section{Effect of the National Energy Plan}

There are presently two proposed governmental taxation policies that will have a significant effect on the economic incentives for industrial users to switch to coal. The first is an additional investment tax credit of $10 \%$ that is being considered for application to the purchase of equipment to fire coal. This investment tax credit will be similar to the present tax credit which is applied to all new investments except that i.t will be an additional credit which will apply solely to the purchase of new coal firing equipment. Like the present tax credit, it can be applied directly to the company's income taxes during the first year of plant operation. The second taxation policy that is being considered is industrial boiler oil fuel tax. There are some subtle variations in the tax structure being considered, but the basic idea is to start with a tax of about $90 \mathrm{c} / \mathrm{bbl}$ in 1979 on oil used as an industrial boiler fuel. The tax will then be escalated to about $\$ 3.00 / \mathrm{bbl}$ in 1985 .

These policies would contribute additional economic incentives to the potential coal users' analysis. However, for the most part, they will be insufficient for all but the large steam users, as depicted in Fig. 12 . This illustrates the effect that the added fuel taxes and investment credits would have for industrial plants considering coal as an option in Houston. For the large plants, the proposed tax policy makes coal look more attractive, but for the sma1.1er installation sizes the incentives are still inadequate.

\section{Allocation of Capital Resources and Other Strategic Planning Issues}

Even if coal was a good economic choice relative to the alternative means of raising steam, it still might be questionable from the standpoint of capital resources. The question of financing takes on much greater importance with coal boilers then with oil- or gas-fired boilers. First, the cost of a coal-fired boiler plant can be four to five times as much 
$(\$ /$ ton $) \quad\left(\$ / 10^{6}\right.$ Biu $)$

ORNL-DWG 78-7529A
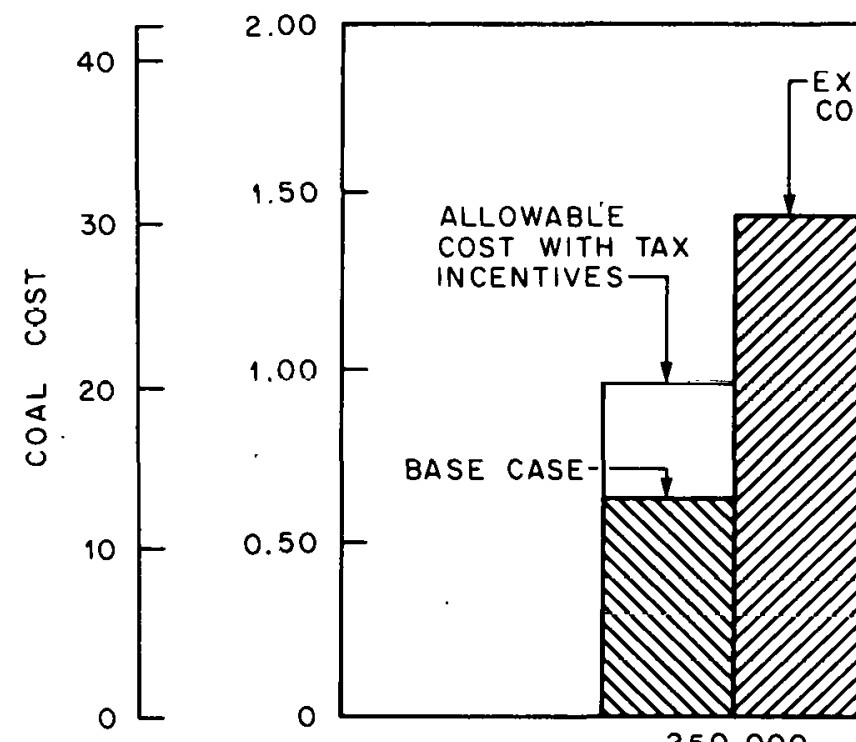

250,000

$1,000,000$

PLANT SIZE (Ib/hr STEAM)

Fig. 12. Comparison of allowable cost with and without tax incentives and delivered cost of low sulfur Wyoming coal in Houston.

as an equivalent sized unit designed to fire oil or gas. Secondly, because of the economy-of-scale characteristics of coal facilities, it is not economically feasible to add coal facilities a little at a time. Thus, in contrast to oil- and gas-fired units where small increments of boiler capacity can be added to accommodate growth and replace obsolete units, the coal decision involves replacement of a major portion of capacity at one time. The above two factors (higher unit cost and one-shot replacement) combine to make the investment decision a major one. As a matter of fact, the capital required for new coal boiler facilities for some plants can rival the original total investment in the entire plant. 
Most companies, and especially the larger ones for which coal would be economically feasible, would not find it difficult to raise the capital required for new coal facilities. But for all. organizations, capital resources are limited. For example, because of internal policies or constraints imposed by agreements with lenders in previous financing arrangements, a company may be required to maintain a given debt-to-equity ratio. Thus, the portion of the project that can be debt-financed may be limited. The financing question is not whether the money can be raised, but rather, how best to utilize finite capital resources from an overall business viewpoint. If one firm spends their money on coal facilities in hopes of a long-term operating cost advantage, while a competitor spends their money on modernization and expansion of production capacity, does the competitor gain a market share advantage that may be difficult to overcome? Investment decisions involving issues of this nature are, of course, commonplace in industry; what is new is that the decisions are associated with raising steam - an activity that was once far less demanding of management attention.

Conversion to coal raises several other strategic planning questions. Because of the size of the investment and the rather long lifetime of the equipment, the decision to install new coal equipment implies that the manufacturing facility with which it is connected will remain in operation for a number of years. So, one obvious issue is: Do we wish to continue making this product and, if so, should it be made at this location? With respect to the effect of increased use of coal on the geographical distribution of industry, it is normally assumed that the effect will be to relocate it nearer coal sources because of the cost of coal transportation. But, there are arguments for the viewpoint that the effect of using coal will be to cause industry to expand in-place, that is, to continue the present trend. The reason is that it is difficult to start small with coal. Thus, the idea of starting a new grass roots plant of modest size may not be as economically attractive, even though the coal transportation cost is low, as adding to an existing plant where the steam demand is already large. 


\section{Environmental Issues}

As far as the potential user is concerned, the three environmental issues that are of greatest importance are:

1. Meeting emission standards for new sources,

2. Trade-off policy,

3. Public acceptance.

The most important environmental consideration from the viewpoint of the potential user is what are the regulations governing emissions and what will it cost to comply with those regulations. Environmental regulations are promulgated at every level of government and are too numerous to be presented here. However, the Federal regulations are reflected in most state statutes and are the easiest to examine.

There are basically three Federal environmental policies that are of concern to a prospective coal user. These are: (1) new source performance standards, (2) emission tradeoffs in noncompliance regions, and (3) the prevention of significant deterioration.

The current new source performance standards are listed in Table 5 (Ref. 8). These regulations apply to fossil fuel fired steam generators which have a heat input rate of 250 million Btu per hour. Although smaller units are not covered under these regulations, most states have regulations that apply. The state emission standards generally increase the allowable emissions above the Federal level for smaller boilers.

The first question that needs to be asked is: Are there combinations of coal types and combustion technologies available to meet existing emission standards? The answer is that they are for most potential users. Even if the emission standards are met, there is still the question of ambient air quality.

Under the Clean Air Act, national primary and secondary ambient air quality standards have been issued (Table 6). ${ }^{8}$ Primary standards define the level of air quality necessary to protect the public health, while secondary defines that necessary to protect the public from any known or , adverse effects. To meet these standards, the states were required to implement plans to reduce emissions. 
Table 5. New source performance standards ${ }^{a}$

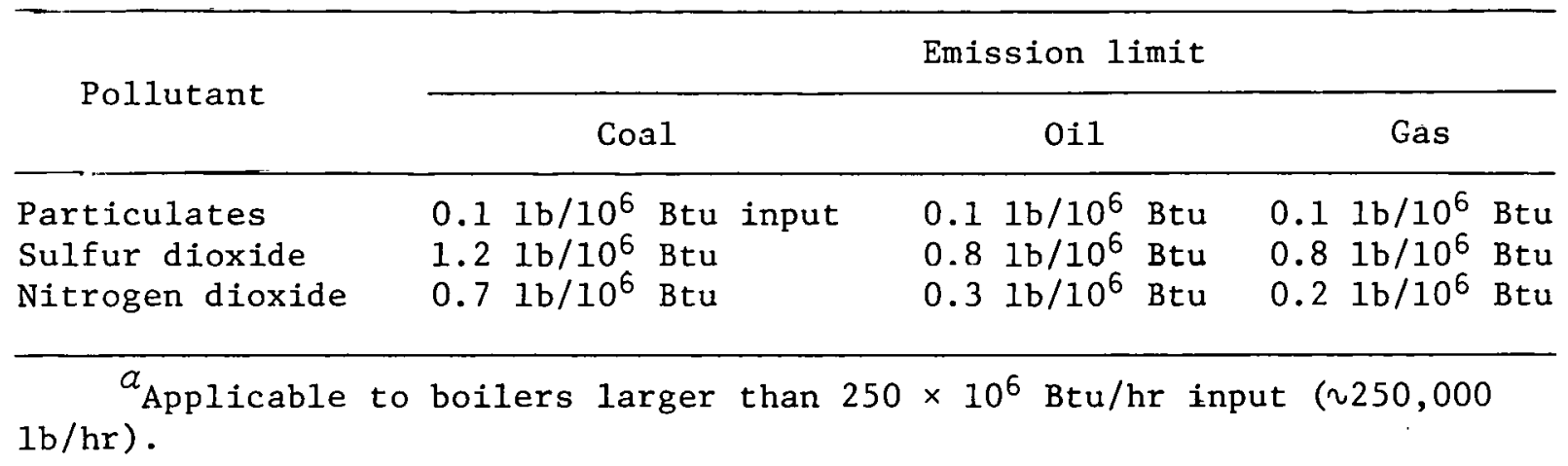

Table 6. National primary and secondary air quality standards

\begin{tabular}{|c|c|c|}
\hline \multirow[b]{2}{*}{ Pollutant } & \multicolumn{2}{|c|}{ Ambient air quality standards } \\
\hline & Primary $^{a}$ & Secondary $b$ \\
\hline $\begin{array}{l}\text { Particulates } \\
\text { Sulfur dioxide } \\
\text { Nitrogen dioxide }\end{array}$ & $\begin{array}{r}75 \mu \mathrm{g} / \mathrm{m}^{3 d} \\
80 \mu \mathrm{\mu g} / \mathrm{m}^{3 c} \\
100 \mu \mathrm{gg} / \mathrm{m}^{3 d}\end{array}$ & $\begin{aligned} 60 \mu \mathrm{g} / \mathrm{m}^{3}{ }^{d} \\
\left.1300 \mathrm{\mu g} / \mathrm{m}^{3}{ }^{(3-\mathrm{hr}} \text { maximum }\right) \\
100 \mathrm{\mu g} / \mathrm{m}^{3}{ }^{(3}\end{aligned}$ \\
\hline
\end{tabular}

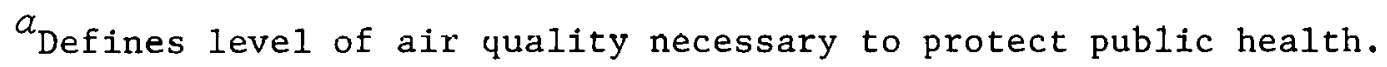

$b$ Defines level of air quality necessary to protect public from any known or anticipated adverse effects.

$c_{\text {Annual geometric mean. }}$

$d_{\text {Annual arithmetic mean. }}$ 
If an area is in "noncompliance" (i.e., it exceeds the maximum permissible level of one or more pollutants), then the Federal regulations require for every increase in emissions there must be an equal or greater decrease elsewhere within that area. This means that emissions from the new plant must be offset by an equivalent decrease in emissions elsewhere in the area. This can lead to rather unusual activities by the prospective coal users, such as paving someone's road to reduce particulates or buying out and shutting down an existing industry (buying "pollution rights").9 The prospects of such activities, so far removed from a company's primary products, discourage consideration of coal, especially by the smaller companies that do not have large legal and technical staffs.

The third policy is the "prevention of significant deterioration" (PSD). Under this policy, each air control region is classified as to air quality. Class I pristine areas, national parks, monuments, etc.; Class II, moderate development which includes all areas not classified I; and Class III, an exemption granted for special areas which allow for more intensive growth. This policy dictates to what extent an area, which is in compliance of Federal ai.r quality primary and secondary standards, can increase the ambient level of pollutants (Table 7). For example, a Class II region that has presently an annual geometric mean level of particulates of $30 \mu \mathrm{g} / \mathrm{m}^{3}\left(45 \mu \mathrm{g} / \mathrm{m}^{3}\right.$ below the primary standard) can only have an increase of $19 \mu \mathrm{g} / \mathrm{m}^{3}$, or a total annual level of $49 \mu \mathrm{g} / \mathrm{m}^{3}$. An increase in emissions that would bring that region over this level would again bring about the trade-off policy. 10

Although the present new source standards are considered by some to be excessively stringent, a large scale conversion from oil and gas to coal that meets these standards will still tend to degrade the local air quality. To compound the problem, areas that are highly industrialized and prime targets for conversion to coal are also areas with poor air quality and have unique problems when considering switching to coal. For example, Southeastern Texas is a highly industrialized area that accounts for a large portion of the nation's industrial natural gas consumption. If the gas- and oil-fired boilers in that region were replaced with units firing coal, which meet the present emission standards, the effect on the local. ambient air quality would be approximated by that shown in Fig. 13 . 
Table 7. National standards for the prevention of significant deterioration

\begin{tabular}{lccc}
\hline & \multicolumn{3}{c}{$\begin{array}{c}\text { Maximum allowable increase } \\
\text { (micrograms per cubic meter) }\end{array}$} \\
\cline { 2 - 4 } & Class I & Class II & Class III \\
\hline Particulate matter: & & & \\
Annual geometric mean & 5 & 19 & 37 \\
24-hr maximum & 10 & 37 & 75 \\
Sulfur dioxide: & & & \\
Annual arithmetic mean & 2 & 20 & 40 \\
24-hr maximum & 5 & 91 & 182 \\
3-hr maximum & 25 & 512 & 700 \\
\hline
\end{tabular}

ORNL-DWG 78-7520R

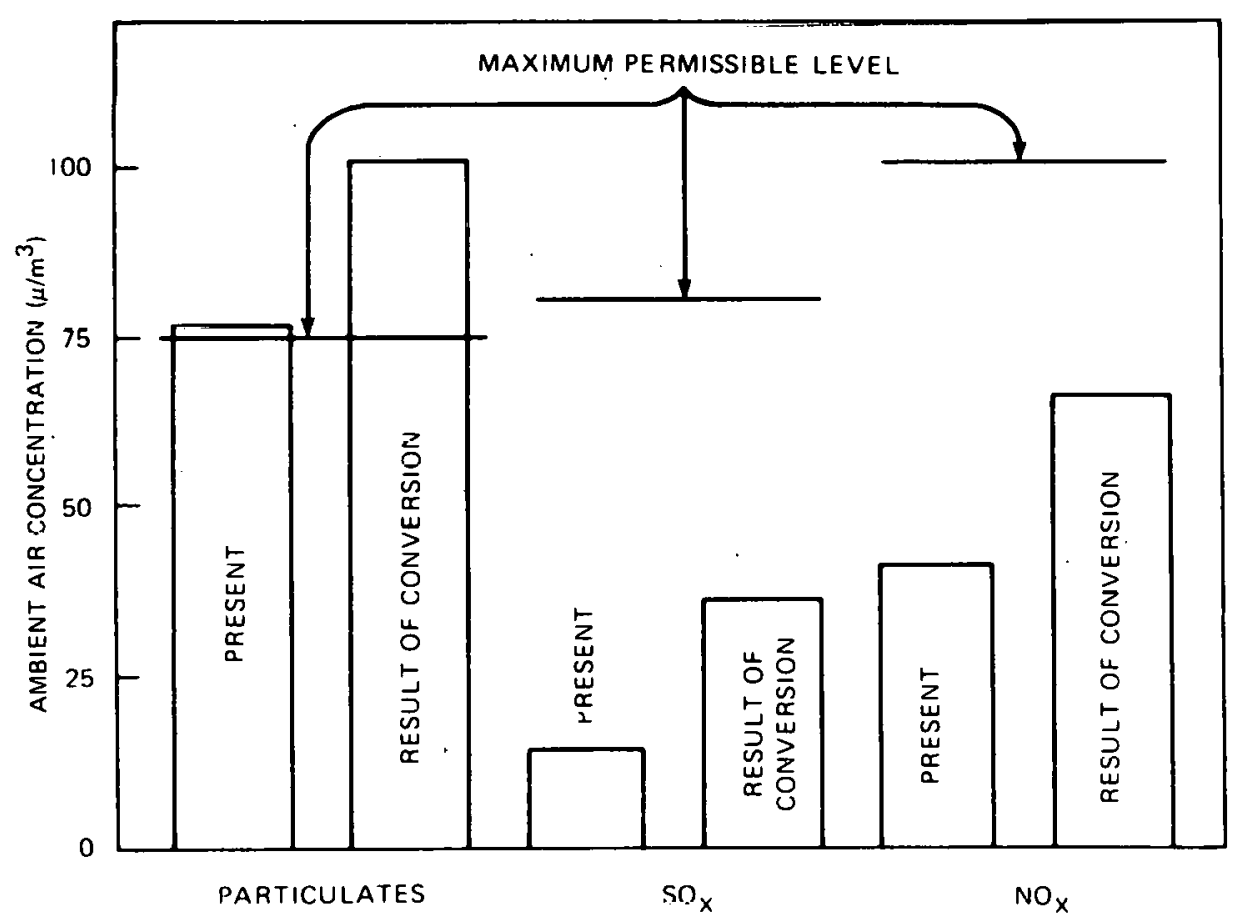

Fig. 13. Estimate of the effect that conversion to coal would have on ambient air quality for southeastern Texas. 
This effect was calculated by. using emission data from the National Emissions Data System and by scaling the emissions to those that meet the new source standards. The change in ambient air quality was based on Air Quality Data Statistics ${ }^{1}$ and adjusted for the increase in emissions. ${ }^{12}$

This example shows a substantial increase in all three pollutants. While the increase in sulfur and nitrous oxides appears to be within the legal limits, the increase in particulates would not be acceptable. This, of course, would be true no matter how much of industry in this area changed to coal because they are already at the maximum limit for particulates. Most other heavily industrialized regions of the country are in che same position, in that they also meet or exceed the ambient limits for one or more pollutants. Of the seven regions considered in this study, four exceed the limits set by the federal standards: Los Angeles Particulates, $\mathrm{NO}_{x}$; Philadelphia $\mathrm{NO}_{x}, \mathrm{SO}_{2}$, Particulates; Chicago, Particulates, $\mathrm{NO}_{x}$; Houston Particulates. Further conversion to coal in New Orleans would bring that area close to the limit in particulates and offset might be required.

In considering the question of public acceptance, it is probably accurate to say that most firms assume that public acceptance in a national sense is achieved by conforming to laws and regulations; that is, they assume that public laws and regulations accurately reflect public values. But, public acceptance on the local level can be an entirely different matter. There is little chance that a plant can switch from, say, natural gas to coal without some degradation of the environment even though all of the legal requlrements are met. If the local rnmmunity believes the degradation will be unacceptable, then this could be a factor in weighing the advantages and disadvantages of converting to coal.

The question of aesthetics, particularly in regard to an industry that is located in reasonable proximity to a residential community, can be an important issue. If the local citizenry feel a new coal-fired power plant will affecl their life-styles or lower "property values," the normally less important question of public acceptance rapidly becomes one of great importance. Industries like to think of themselves as "good neighbors"; local public acceptance could be a swing issue, especially if other cunsiderations show coal to be a marginal proposition. 


\section{Risk and Uncertainty}

Throughout the preceding discussion, there is the implication that uncertainty about the future is one of the most constant aspects of industry's deliberations on converting to coal. Future relative prices of gas, oil, and coal are very uncertain and, of course, fuel prices are the single most important factor in assessing the economic feasibility of coal; within a plausible range of assumptions, one can "prove" that coal is either a very good or a very poor economic choice. Regulatory requirements, especially environmental requirements, is another area of uncertainty. Will low-sulfur coal be permitted without stack gas scrubbing or will the "best available" pollution control technology be required? If a plant is designed to meet today's standards, will it need to be retrofitted soon after construction is completed to meet more stringent standards? These are some of the questions that are being asked, and most of them can be boiled down to: What is to be the National policy regarding energy and environment? In the face of uncertainty, the natural response is to wait until things clear up, and that is generally what is happening.

Most of the present risks in converting to coal are not related to technical matters. But, when the nontechnical risks are high, the technical choices tend to be conservative. On top of the other uncertainties, no one wants to buy a machine that may not work. This suggests that the new technologies being developed under Federa.1 sponsorship must be thoroughly demonstrated before a commercial market develops.

\section{THE ALTERNATIVES}

In an effort to find possible alternatives to on-site direct coal combustion, two concepts were investigated: (1) central steam generation and (2) the area coal depot. The philosophy behind both of these concepts is to provide additional economic incentives for potential coal users who have a sma11-to-moderate steam load (250,000-500,000 1b/hr steam). The objective is to construct a large facility that can be shared by a number of users at a lower distributed cost to each user. Further, a large 
central facility should be able to secure coal contracts which are more favorable and have the advantage of lower coal transportation costs.

\section{Central Steam System}

The central steam system is simple in concept. It consists of a relatively large coal-steam plant (for this analysis $2 \times 10^{6} \mathrm{lb} / \mathrm{hr}$ steam was used) that provides steam to a number of users located a moderate distance from the central coal plant. Figure 14 illustrates a possible arrangement of the central steam system and its users. The steam is delivered at $750^{\circ} \mathrm{F}$ and $650 \mathrm{psig}$, which are the same steam conditions used throughout this study and used here for comparison. Therefore, the steam conditions leaving the central plant have to be somewhat higher to account for the pressure and temperature losses through the pipeline. These higher conditions are considered in the design of the boiler system and are accounted for in the capital costs. It is assumed that the central steam boiler would be designed so that it could operate at 1000 psi and $900^{\circ} \mathrm{F}$, which would be sufficient to accommodate any pressure or temperature losses considered. This would Increase the total boiler plant capital costs by about $4 \%$.

ORNL-DWG 78-20536

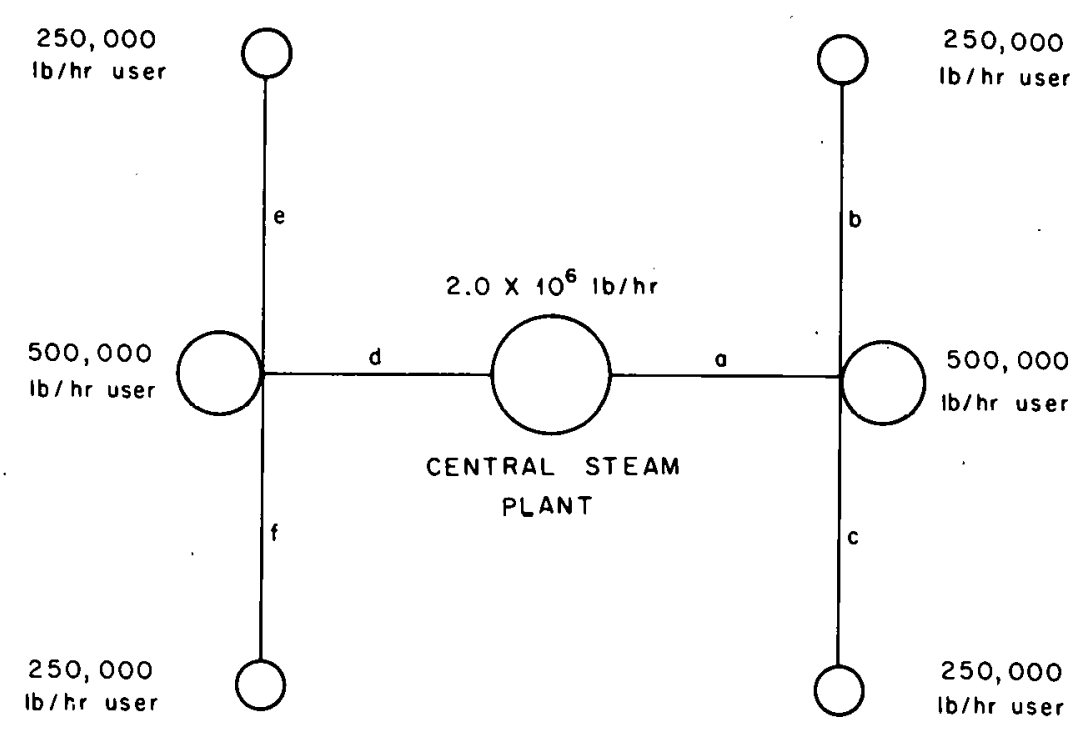

Fig. 14. Example central steam system. 
The capital costs for the steam distribution system were developed by Hydroscience, Inc., ${ }^{13}$ and adapted to the steam flow rates considered in this study. The optimum cost of a pipeline is, of course, a tradeoff between capital costs and pressure drop. That is, for the same flow rate, a larger pipeline has a smaller pressure drop but higher capital costs. This tradeoff was to some extent incorporated in the capital costs of the pipeline, but these costs do not necessarily represent the optimum.

For the purpose of this analysis, the steam system illustrated in Fig. 14 is used. The total capital costs for the steam supply system are given in Tables 8 and 9 .

Table 8. Capital cost estimate for central steam system without scrubbers

\begin{tabular}{ll}
\hline \multicolumn{1}{c}{ Item } & Cap1tal cost $\left(x 10^{6} \$\right)$ \\
\hline Boiler plant & $62-93$ \\
Coal handing equipment & 7 \\
$\quad$ Total plant capital & $\frac{69-100}{13}$ \\
Steam network & $\overline{82-113}$ \\
$\quad$ Total steam system & $8.7-12.1$ \\
Escalation during construction @ 7\% & $12.5-17$ \\
Interest during construction @ 9\% & $\frac{103.2-142.1}{10 \%}$ \\
Total capital cost & \\
\hline
\end{tabular}

Table 9. Capital cost estimate for central steam system with scrubbers

\begin{tabular}{ll}
\multicolumn{1}{c}{ Item } & Capital cost $\left(\mathrm{x} 10^{6} \$\right)$ \\
\hline Boiler plant & $62-93$ \\
Coal handling equipment & 7 \\
Scrubbers & 18 \\
$\quad$ Total plant capital & $\overline{87-118}$ \\
Steam network & 13 \\
$\quad$ Total steam system & $\overline{100-131}$ \\
Escalation during construction @ $7 \%$ & $10.7-14$ \\
Interest during construction @ 9\% & $15.3-20$ \\
$\quad$ Total capital cost & $\overline{126-165}$ \\
\hline
\end{tabular}


The engineering economic analysis of the central coal system was undertaken in the same vein as in the previous section for on-site combustion and with the ground rules in Table 1 . For comparison, two industrial size steam loads are used $(250,000 \mathrm{lb} / \mathrm{hr}$ and $500,000 \mathrm{lb} / \mathrm{hr})$. The price of coal was calculated that would be the maximum an industrial user could afford and yet provide enough difference in operating cost between the 011 and coal systems to pay for the extra capital of the coal plant. In this case, it is assumed that the central steam customer must pay for the share of the capital and operating costs of the central plant that is proportionate to his share of delivered steam. The allowable or breakeven costs are presented as the cost of coal that can be afforded at the project start (1977) and include the escalation and discount factors indicated in Table 1.

The results as shown in Figs. 15-18 indicate that in each case a central steam system improves the incentives to switch to coal. First, the cost of the large central steam plant, plus the steam distribution system, is less than the cost of individual boiler systems. Secondly, the central system can obtain lower rall rates through larger shipments than would be possible for the individual industrial users.

The improvement is most pronounced for the smaller sizes, but for systems as large as $500,000 \mathrm{lb} / \mathrm{hr}$ steam, the advantage of a central steam system is substantial. The same advantage applies to either using low sulfur coal or high sulfur coal with scrubbers. Although the central steam system is constrained to industrial regions which have a highly dense steam load, there are at least 34 sites in the United States that would apply. ${ }^{2}$ As the steam load becomes less dense, the cost advantage decreases because of the higher capital costs for longer steam supply lines. In view of this, another option was considered.

\section{Area Coa1 Depot}

The rationale behind the area coal depot is to develop a system which is simple, does not interfere with the users' operation, and has the potential of decreasing both capital and operating costs. The coal depot is 


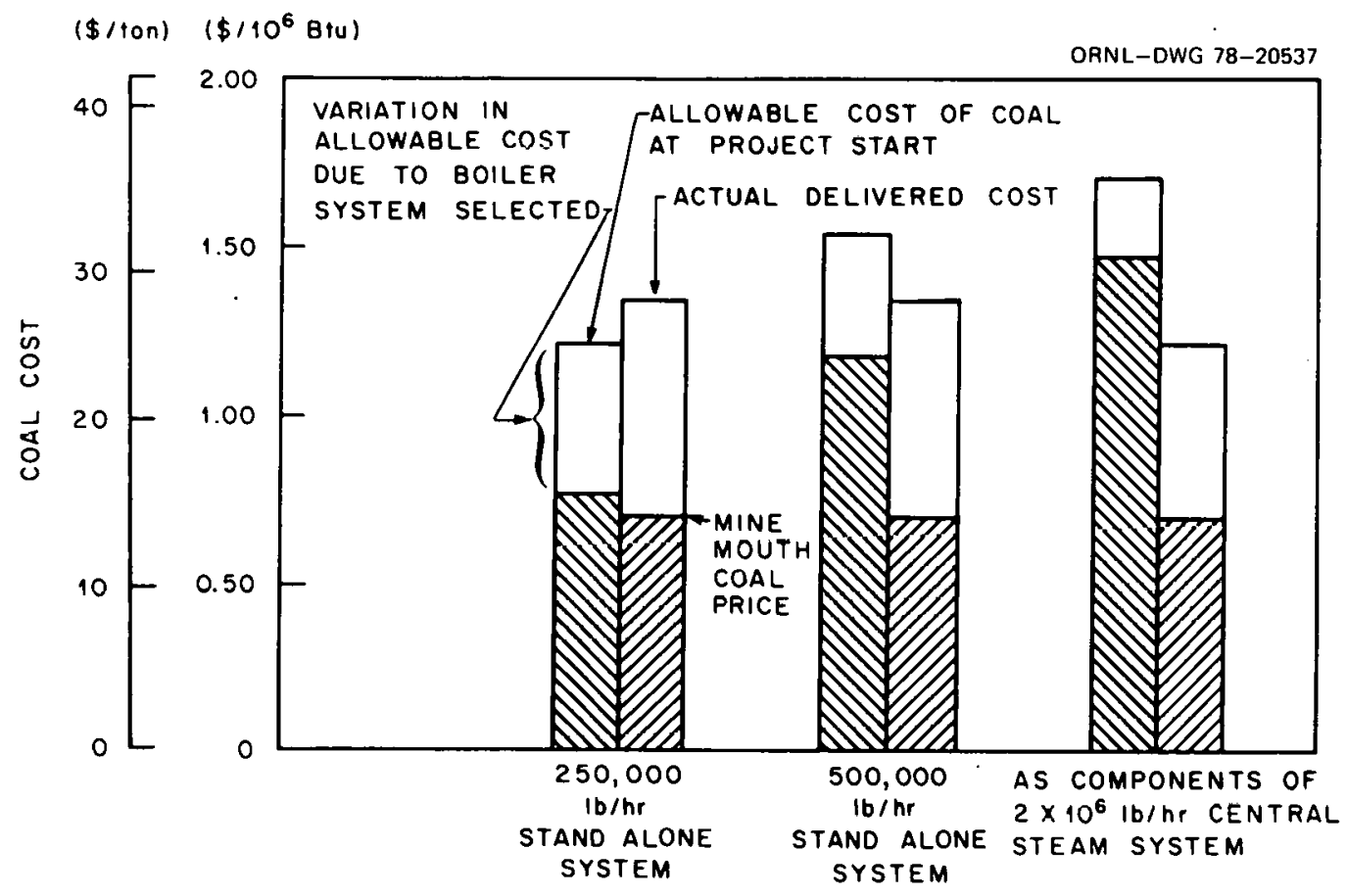

F1g. 15. Comparison of allowable and delivered coal costs for central steam system and its components as stand alone systems, burning low sulfur Wyoming coal in Chicago.

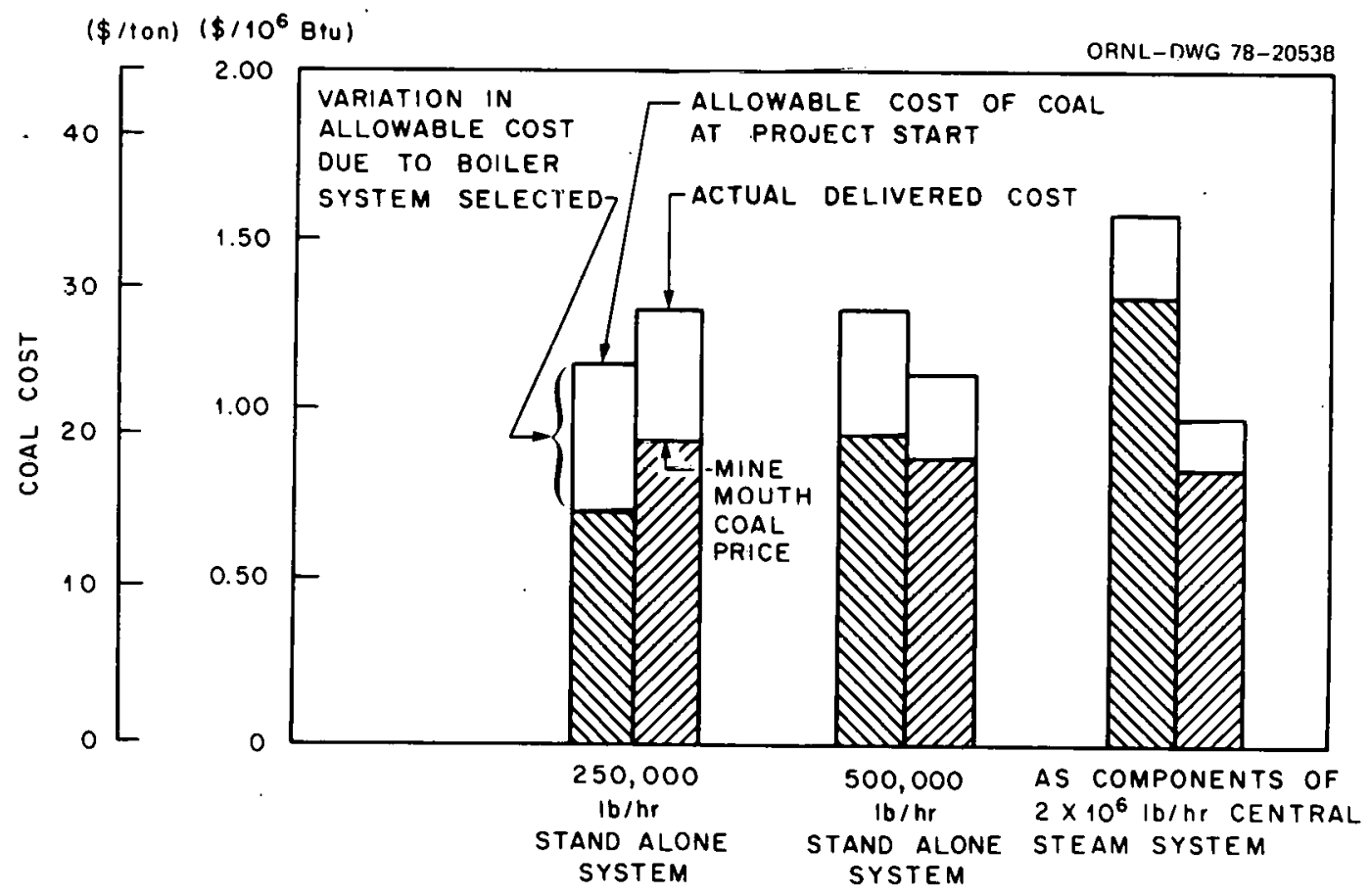

Fig. 16. Comparison of allowable and delivered coal costs for central steam system and its components as stand alone systems, burning high sulfur Illinois coal in Chicago. 


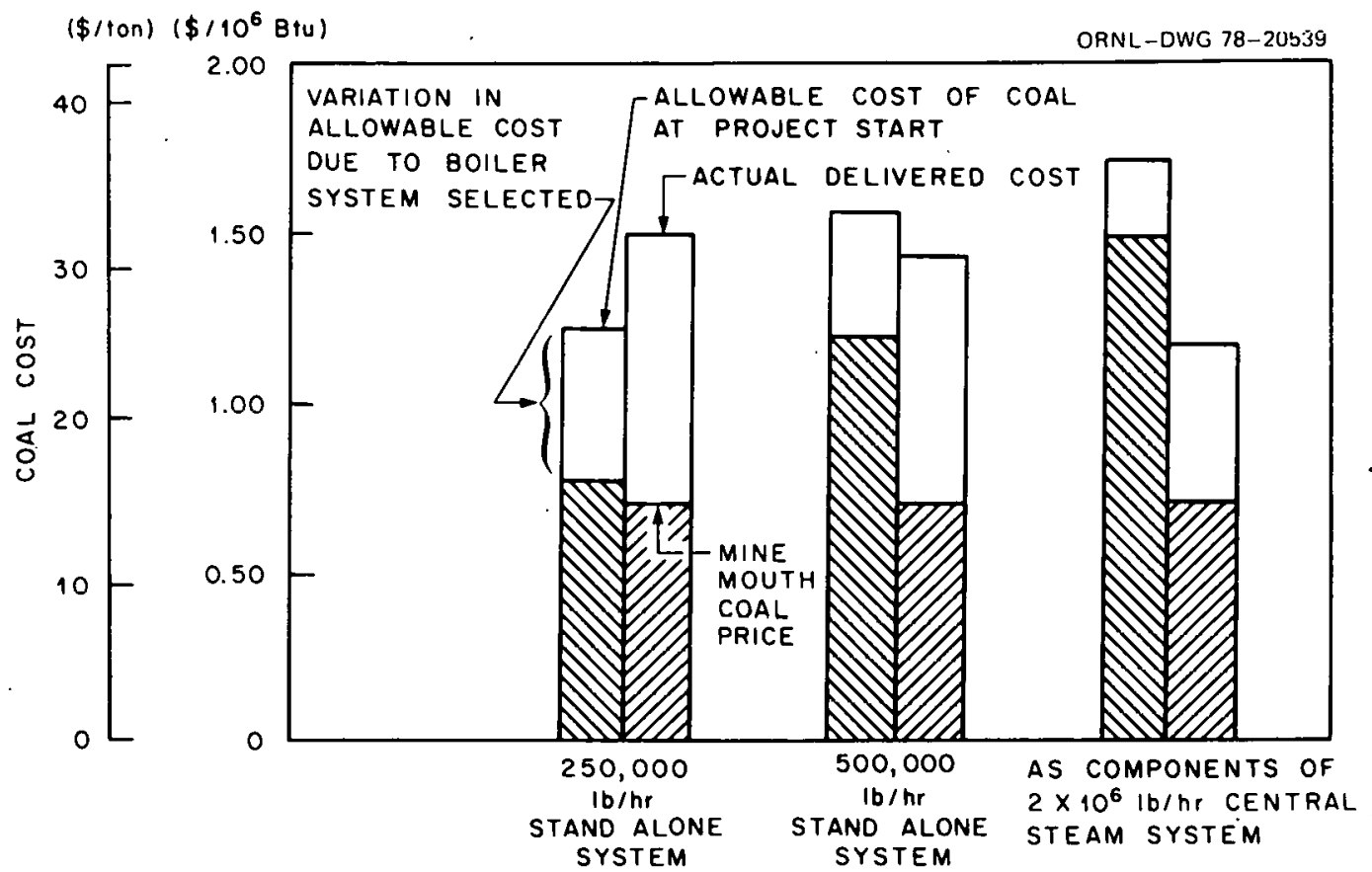

Fig. 17. Comparison of allowable and delivered coal costs for central steam system and its components as stand alone systems using low sulfur Wyoming coal in Houston.

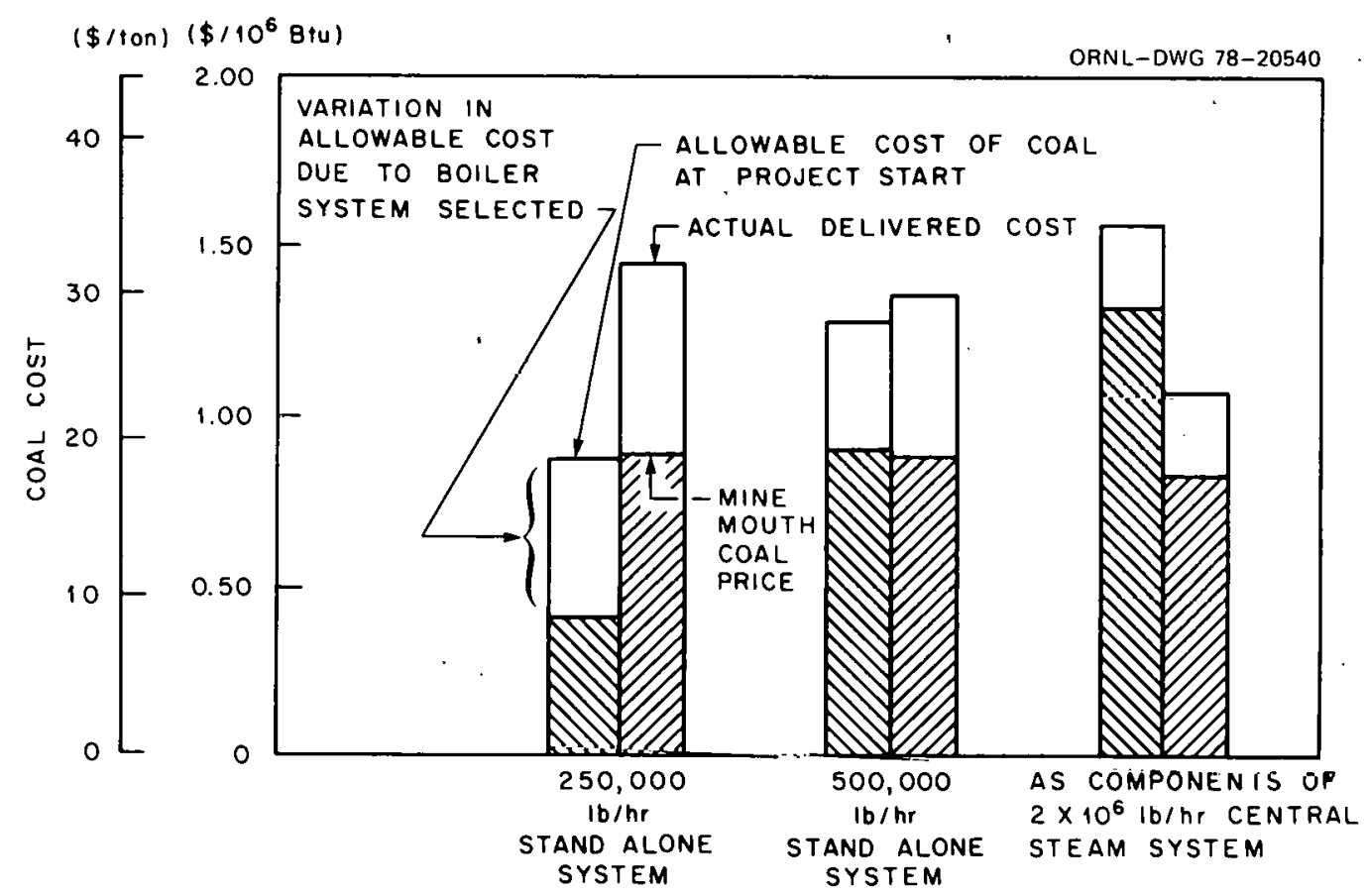

Fig. 18. Comparison of allowable and delivered coal costs for central steam systeui and its components as stand alone systems, using high sulfur Illinois coal in Houston. 
envisioned as a terminal that would receive unit trains, unload the coal, provide storage, perhaps size the coal and distribute it to subscribers within the area (probably 30-50 miles). The coal could be sized for stoker firing or used in fluidized beds. In some cases, the coal depot may just serve as a storage and distribution system. This would depend on the delivery systems chosen and utilization of the fines that would be generated in the process of sizing. A gcneral schematic of the concept is shown in Fig. 19.

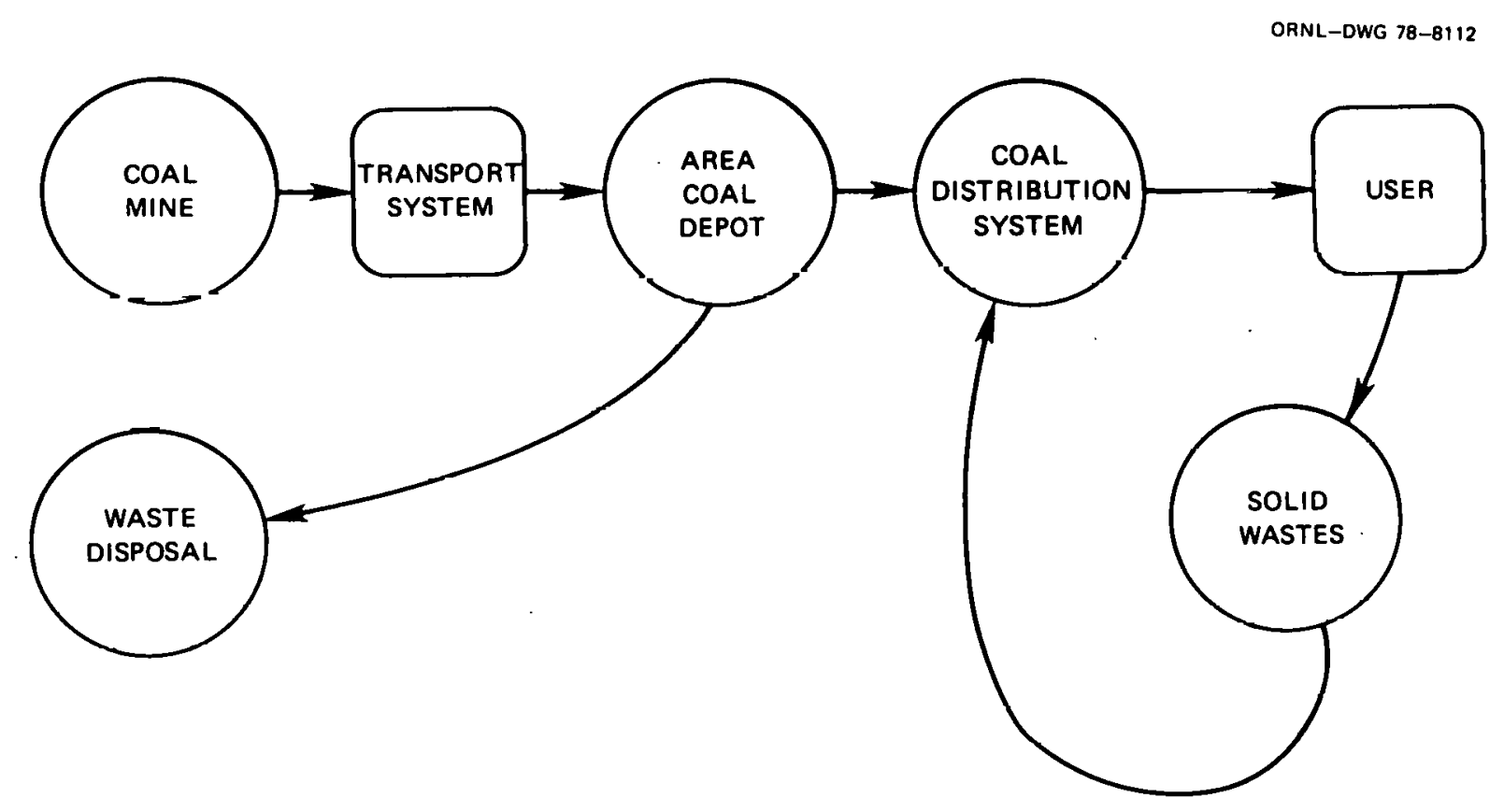

Fig. 19. Area coal depot. 
For the purpose of this study, five distribution systems were considered: (1) truck transportation, (2) local rail delivery, (3) pneumatic pipeline, (4) hydraulic delivery in an oil slurry, and (5) the Tube Express system. Truck and rail transportation require no development and are only dependent on the conditions of the local roads and the availability of rail lines. In the pneumatic transport system, the coal would be sized to about $1 / 4 \mathrm{in}$. and injected through a Venturi feeder into a compressed air stream. The pneumatically transported coal would travel through a steel pipeline to the user where the coal would be separated with a series of cyclones and the dust removed with a fabric filter.

The coal-oil slurry is a similar concept where the coal is wixed with a light oil and then pumped to the user. At the users' end of the pipeline, the coal is separated from the oil and the majority of the oil returned to the depot for recycle. The oil that adheres to the coal would be burned in the furnace.

The third pipeline-transport system is one that is being commercialized by Tube Express Systems, Inc. This consists of a pipeline that acts as a guide way for cargo vehicles. The vehicles are pushed through the pipe by a column of low pressure air.

Since one of the primary purposes of the area coal depot is to. reduce transportation costs, it is important that the distribution costs are low so that they do not offset the savings in transportation. The five systems were analyzed with this in mind. At the outset, the pipeline transportation systems seemed to be a natural match for a coal distribution network, however the cost comparison with the other modes of transportation seemed to indicate otherwise. As can be seen in Table 10, the pneumatic and hydraulic transport systems are more expensive than rail or truck delivery. This is primarily because the pipelines must be small to accommodate the small flow rates of coal (less than 60 tons/hr) and, as a result, the economy of scale dominates. Similarly, the Tube Express System is not attractive to rail and truck transportation even with the estimated costs in their own literature. ${ }^{14}$

Although the costs used for truck and rail delivery are based on existing systems and do not represent the cost that would be incurred if 
Table 10. Estimated distribution costs

\begin{tabular}{lc}
\hline \multicolumn{1}{c}{ Method } & Cost $(\$ /$ ton-mile $)$ \\
\hline Truck & $0.05-0.1$ \\
Local rail & $0.04-0.06$ \\
Pneumatic pipeline & $0.12-0.40$ \\
Coal-oil slurry & $0.10-0.30$ \\
Tube Express & $>0.08$
\end{tabular}

new investments in highways and rai,lroad beds were required, they are considered representative and were used in the economic comparison.

As in the other comparisons, the economlc analysis of the area coal depot was made from the users' viewpoint. Again, the cost of coal that can be afforded at the project 'start, which would result in enough savings in operating cost over oil at $\$ 14 / b b 1$ to pay for the sapital invectmcnt; was calculated. It was assumed that the boiler systems that would be used in conjunction with an area coal depot would have negligible offloading and storage facilities. Further, the distribution costs were arrived at by combining the costs of operating the coal depot and the cost of delivering the coal to the user by a local rail shipment (Table 11). These distribution costs are then added to the transportation costs and the comparisons conducted as they were previously.

Table 11. Cost of coal depot and distribution system ${ }^{a}$

\begin{tabular}{|c|c|}
\hline Capital cost & $\$ 4,200,000$ \\
\hline $\begin{array}{l}\text { Annual costs } \\
\text { Capital @ } 24 \% \text { fixed charge rate } \\
\text { Operation \& maintenance (O\&M) }\end{array}$ & $\begin{array}{r}\$ 1,000,000 \\
210,000\end{array}$ \\
\hline Total annual costs & $\$ \overline{1,210,000}$ \\
\hline $\begin{array}{l}\text { Unit costs } \\
\text { Depot O\&M } \\
\text { Distribution @ } 0.05 \$ / \text { ton-mile } \\
\quad(30 \text {-mile delivery) }\end{array}$ & $\begin{array}{l}1.2 \$ / \text { ton } \\
1.5 \$ / \text { ton }\end{array}$ \\
\hline Total unit costs & $\overline{2.7 \$ / \text { ton }}$ \\
\hline
\end{tabular}


As with the central steam supply system, the area coal depot provides additional incentives to the industrial steam user who is considering a switch to coal as is shown in Figs. 20-23 for Houston and Chicago. (Other sites are detailed in the main report. ${ }^{2}$ ) These economic incentives are achieved primarily through the savings in transportation costs. The additional cost of the depot and the local distribution cost are offset by the savings achieved through more favorable coal contracts and substantial savings in rail tariffs because of the higher volume of coal and the ability to utilize unit trains rather than single car or partial train shipments. Further, the coal depot relieves the user of the need to install a substantial coal handling facility and a large storage yard, which saves both capital and operating costs.

The actual incentives vary somewhat from region to region. For instance, Minneapolis showed very promising results when low sulfur coal without scrubbers was considered. On the other hand, considering high sulfur Western Pennsylvania coal in Philadelphia indicated no economic incentives to go to a coal depot. These results can be generalized as follows: For coal options where the distance from the coal source is relatively large, the coal depot can lower the effective cost of coal handling equipment and lower the transportation costs. Examples which show improved economic incentives are Minneapolis, Houston, New Orleans, Chicago, and Los Angeles. However, for locations that are near the coal mines or where there is not a distinctive cost advantage in the rail tariffs for large shipments, then the coal depot is not as attractive. Examples are Philadelphia and high-sulfur Tennessee coal in Knoxville. In these cases, the coal unloading facilities considered for the onsite option were minimal and therefore the savings were small. Also, the transportation costs are small.

\section{CONCLUSIONS}

of all the energy consuming sectors, industry represents the best potential for replacing oil and gas with coal. In addition to being the largest consumer of primary energy, industry is the largest consumer of natural gas and a major user of oil. Much of its fuel is used to 


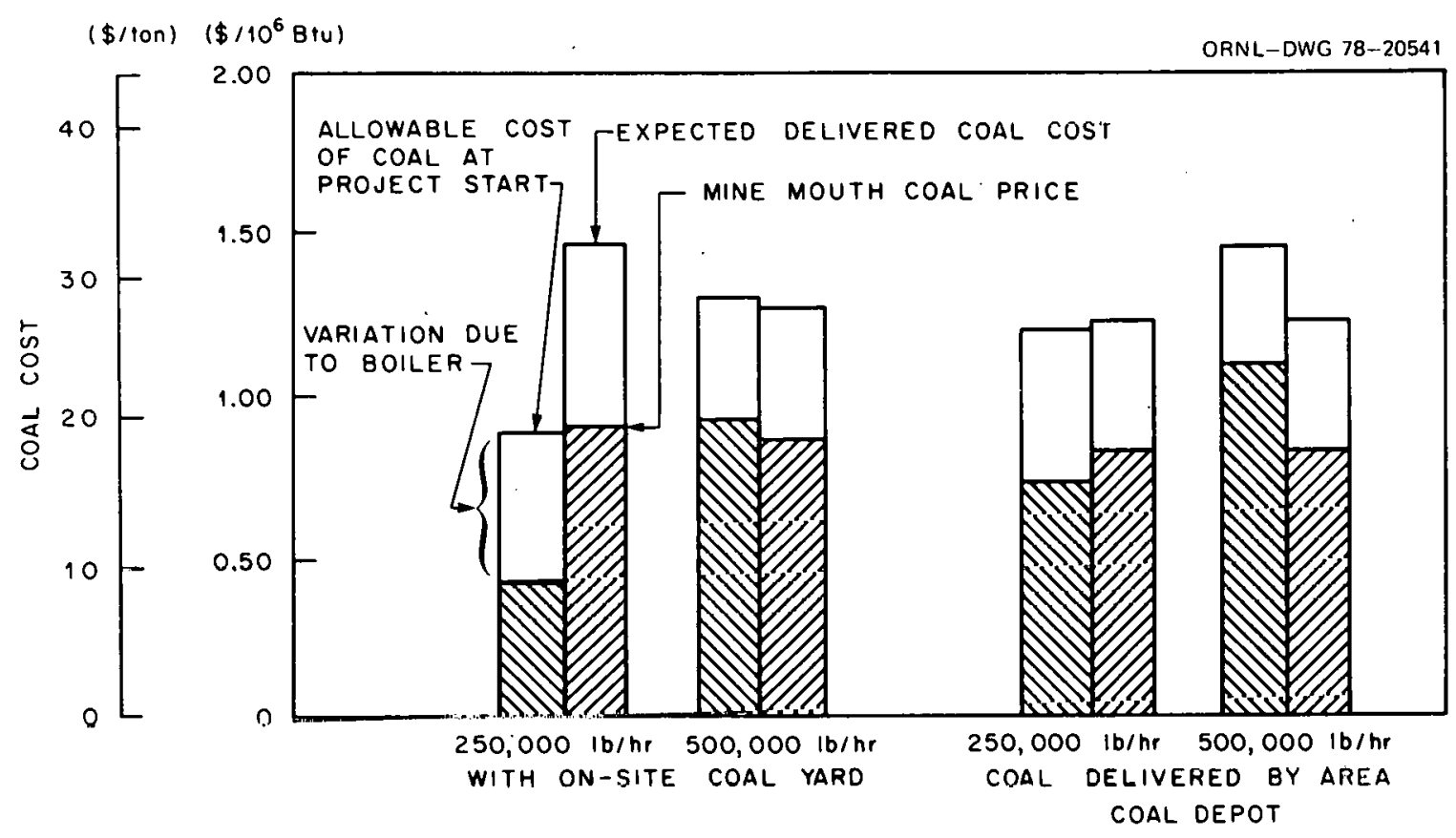

Fig. 20. Comparison of allowable and delivered cost of coal for Installations with and without coal depot, burning high sulfur Illinois coal in Houston, with scrubbers.

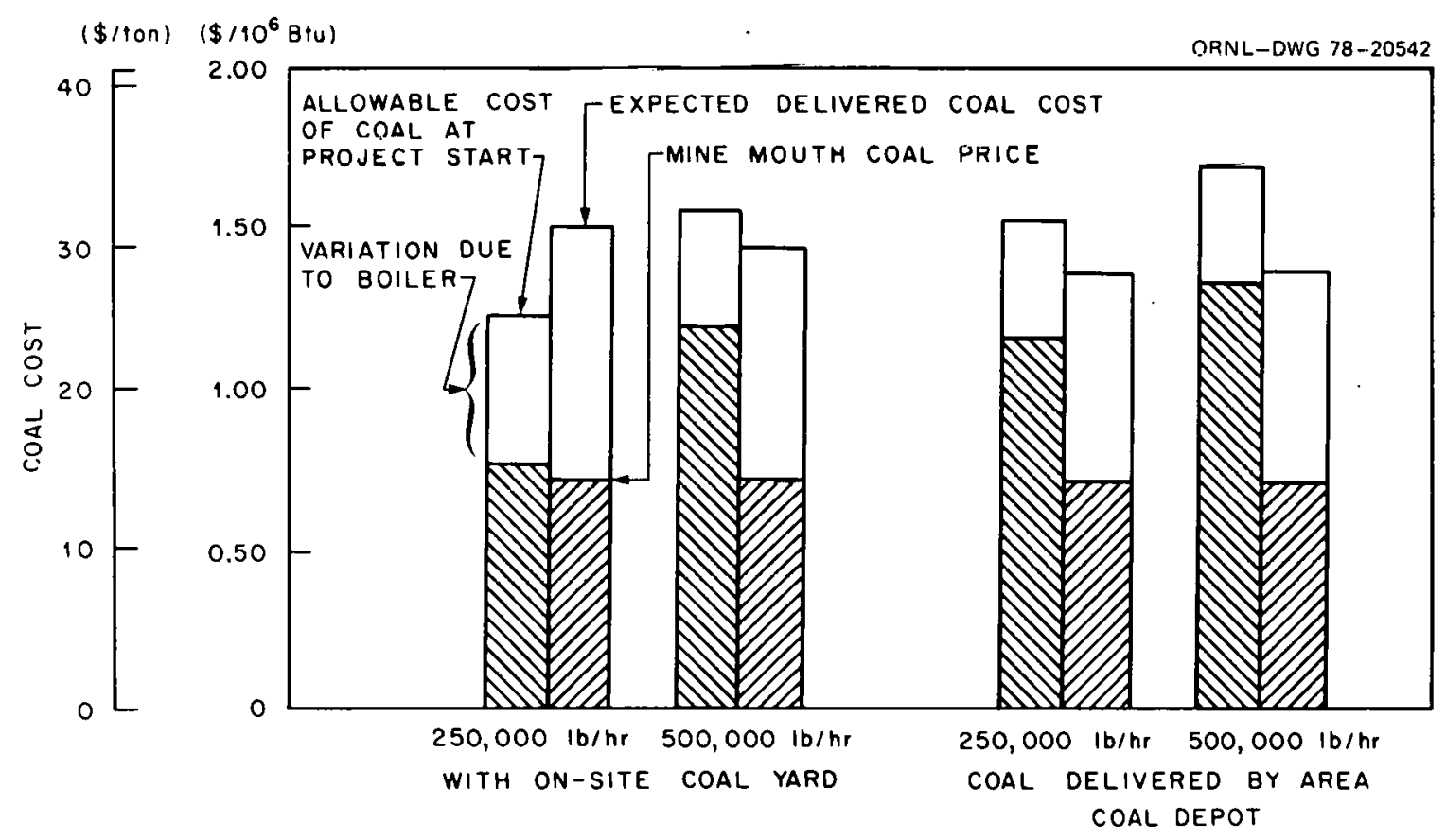

Fig. 21. Comparison of allowable and delivered cost of coal for installations with and without coal depot, burning low sulfur Wyoming coal in Houston. 


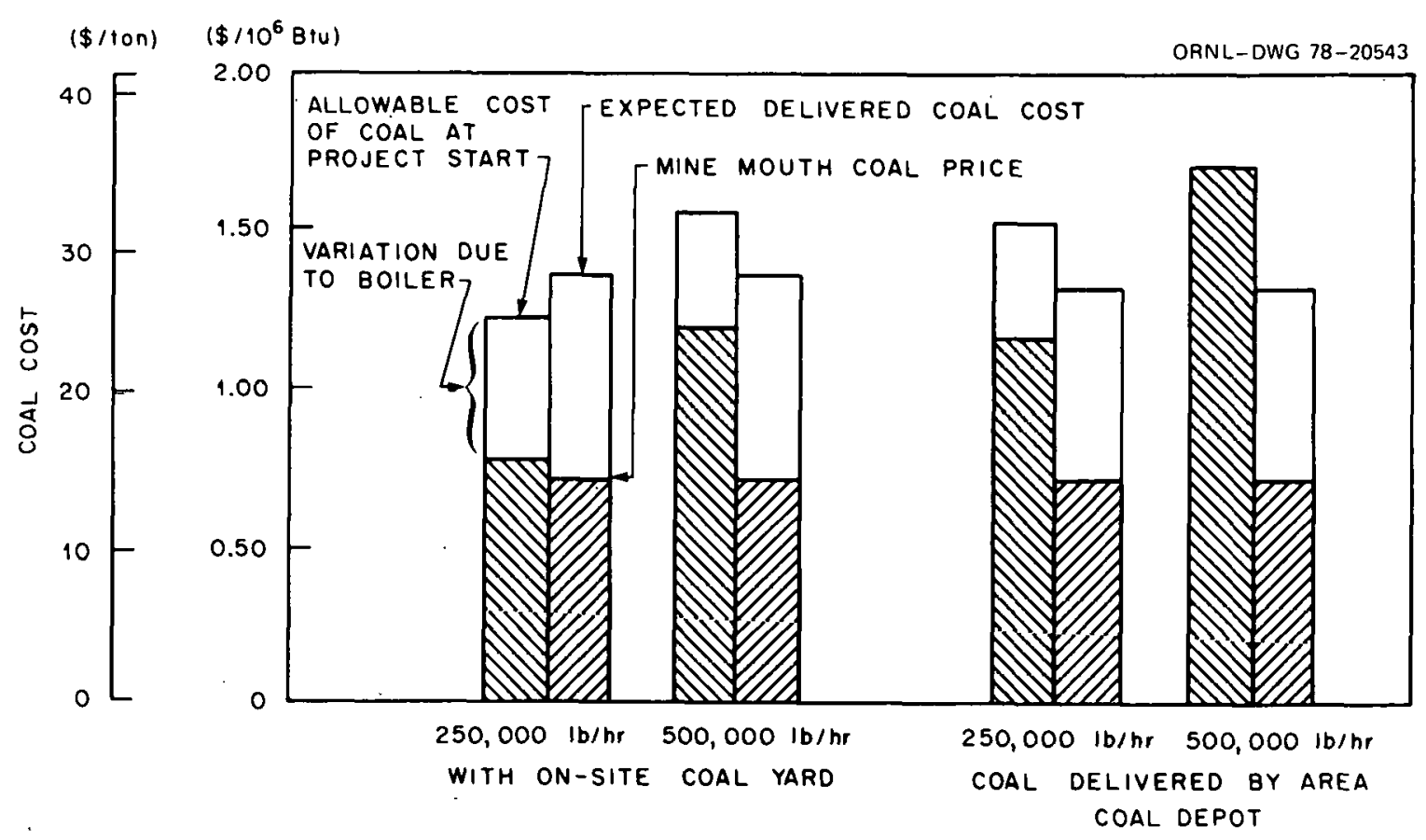

Fig. 22. Comparison of allowable and delivered cost of coal for installations with and without coal depot, burning low sulfur Wyoming coal in Chicago.

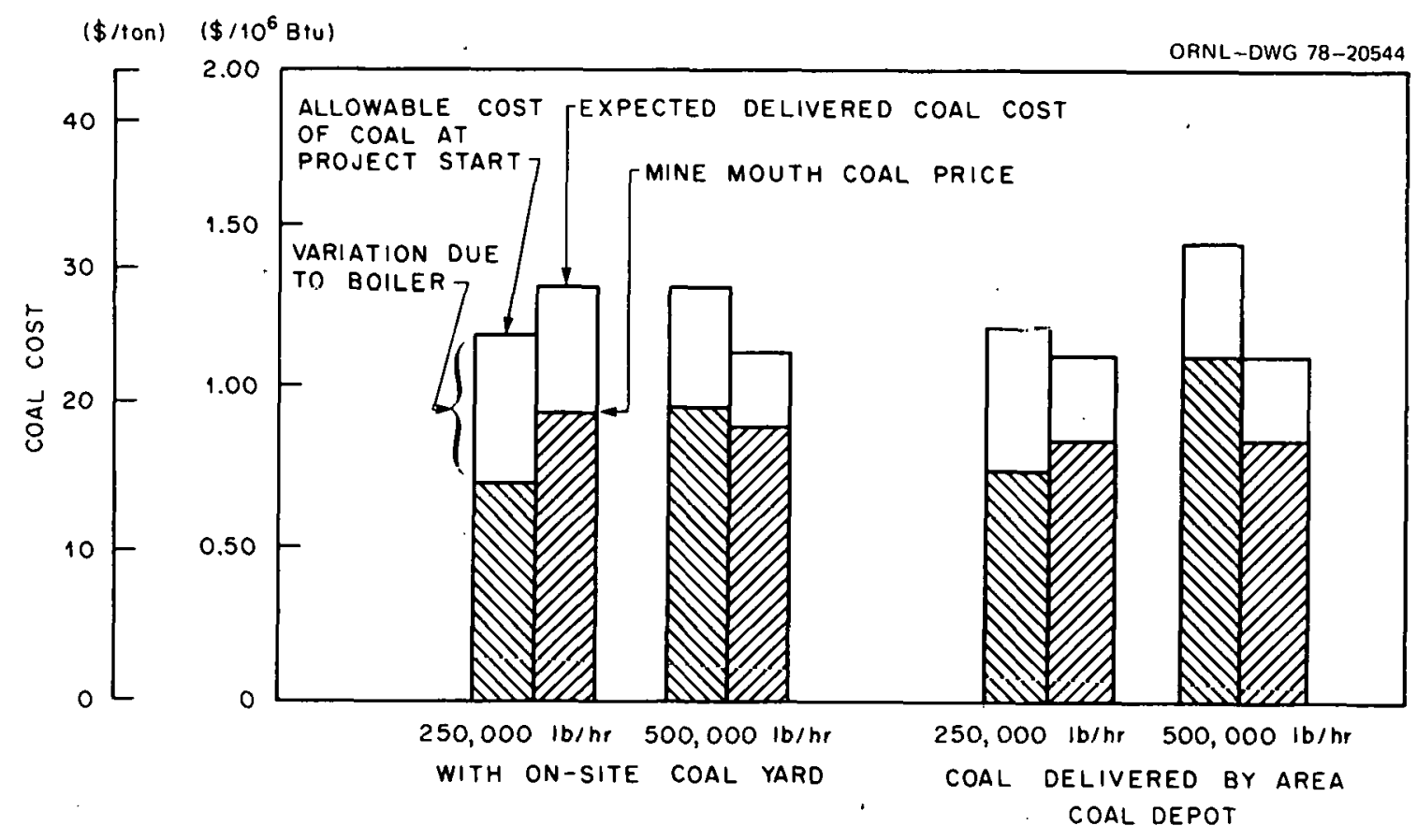

Fig. 23. Comparison of allowable and delivered cost of coal for installations with and williout coal depot, hurning high sulfur Illinois coal in Chicago, with scrubbers. 
raise steam, an end-use that is technically compatible with the direct combustion of coal.

The direct combustion of coal in boilers is a well developed technology. Conventional pulverized-coal and stoker-fired boilers are commercially available from several U.S. manufacturers. Conventional boilers coupled with low sulfur coal or with flue-gas scrubbers can meet the present (mid 1977) emission standards for new sources. However, many industrial energy users are skeptical of flue-gas desulfurization as a practical choice at the present timc: But as more experience is gained, the acceptability of scrubbers is likely to improve.

of the developmental technologies, fluidized bed combustion appears to be the most promising. Fluidized bed boilers have the potential for meeting present and future emission standards more economically than conventional coal-fired boilers. Another advantage, especially for industrial applications, is their flexibility in accepting a wide range of fuels. Nevertheless, most industrial energy users do not consider fluidized bed boilers to be a commercial option even though the potential advantages are recognized. Industrial acceptance must await extensive demonstration under typical industrial conditions.

The single most important barrier to the wide acceptance of direct coal combustion is the question of ernnomico. For musl instailations presently burning natural gas, conversion to oil firing is an option at some modest capital investment. However, converting a boiler designed to fire natural gas to coal firing is not a practical consideration. In general, the choices which industry has are either converting their gasfired boilers to oil firing, or building new coal-fired units. But the economic incentives for building new on-site coal-fired boilers are generally weak. For all of the seven regions considered (Houston, New Orleans, Chicago, Minneapolis, Los Angeles, Philadelphia, and Knoxville), the large coal installations ( $1 \times 10^{6} \mathrm{lb} / \mathrm{hr}$ steam) appeared to be marginally attractive over oil. But for smaller sizes, the economy of scale and increased transportation costs make coal less attractive. Houston, Texas, and New Orleans, Louisiana, which are sites representative of the highly industrialized Gulf Coast, are distant from either the eastern or western coal fields. Because the transportation costs are high, the 
economic incentive to shift to coal is constrained to the largest sizes $(\geq 1,000,000 \mathrm{lb} / \mathrm{hr})$. For sites that are near eastern coal mines (Chicago, Knoxville, and Philadelphia), coal may be economically attractive for some medium size steam users $(500,000-1,000,000 \mathrm{lb} / \mathrm{hr})$. In general, for industries with steam demands below 500,000-700,000 1b/hr, the economic incentives are found to be lacking. These results indicate that for $70 \%$ or more of industry, coal combustion is not an economic choice.

Concerning the effects of the proposed tax provisions of the National Energy Plan, it was found that the boiler fuel taxes on oil and the investment tax credits for coal equipment would indeed improve the economic incentives for converting to coal. However, for steam demands below $500,000 \mathrm{lb} / \mathrm{hr}$ these incentives are inadequate.

For most of industry, if the fuels are available, continued burning of oil and gas is permissible under present regulations; on the other hand, conversion to coal may be prohibited by environmental regulations. Meeting new source performance standards is possible with available technology, and the issue is primarily one of cost. However, for many industrial regions of the country, simply meeting emissions standards is not enough. Four of the seven industrial regions considered in this study (Los Angeles, Houston, Philadelphia, and Chicago) are in violation of federal ambient air quality standards. For these regions, conversion to direct coal combustion would require an abatement of emissions elsewhere. Concern over future environmental standards and the inability to meet the offset requirements in noncompliance areas are serious barriers to increased use of coal in the industrial sector.

Even without a substantial conversion to coal, new stricter emission standards are being promulgated. These standards will require more stringent controls of particulates and nitrous oxides and will probably require some form of sulfur removal regardless of the sulfur content of the coal. A preliminary economic analysis indicates that requiring scrubbers to fire a low-sulfur coal seriously detracts from what was, for most regions, the best economic option. Further, these regulations offset most of the incentives gained through the proposed tax provisions of the National Energy Plan. 
Risk and uncertainty are questions inherent to the economic decision process. Future relative prices of oil, gas and coal are very uncertain and of course fuel prices are the single most important factor in assessing the economic feasibility of a new steam system. There is also concern about meeting today's environmental requirements and great uncertainty concerning future requirements. In the face of uncertainty, the natural response is to wait, and in general that is what is happening. Most of the present risks in converting to coal are not of a technical nature. But, when the nontechnical risks are high, the technical choices tend to be conservative. Compounded with other uncertaintles, an unproven combuotion device is not an attractive option. This suggests that the new technologies being developed under Federal sponsorship must be thoroughly demonstrated before a commercial market develops.

Two alternatives to on-site coal combustion were investigated. These are the central steam system and the area coal terminal. Both concepts offer the industrial users a savings in capital through large central facilities and lower delivered coal costs because the large central facility can purchase and transport coal in larger volumes.

The central steam concept provides substantial economic incentives for users who are in an area with a relatively dense steam demand. For all the regions considered, the central steam system offered strong economic incentives over both on-site coal combustion and oil combustion for prospective users who have a small to moderate steam demand $<500,000 \mathrm{lb} / \mathrm{hr}$.

While the analysis of the area coal terminal did not indicate as dramatic an improvement in the economic incentives as demonstrated by the central coal system, it did provide some economic advantages in certain regions of the country. These regions are characterized by high transportation costs. Users in regions which are close to the coal mines would not find an area coal terminal as attractive. However, the terminal offers some advantages beyond economics. For many industrial users the land area for coal storage, handling facilities and rail lines is not available. For these plants, coal is not an option regardless of the economic incentives; and, to this end, the coal terminal offers some relief. 


\section{RECOMMENDATIONS}

- On Technology Development

It is recommended that greater emphasis be placed on developing and demonstrating fluidized bed technology for industrial applications. This technology shows some real promise for improving the economic incentive to convert to coal. However, because the technology is undemonstrated, the uncertainty associated with it is too high for industry to take the financial risk that would be required. An extensive demonstration program conducted under industrial conditions is needed to inspire the confidence required to commerclalize tliese systems.

The present development program, though a step in the right direction, cannot be considered an industrial demonstration of fluidized bed technology. It is recommended that DOE undertake a true demonstration program, one in which boilers are designed and built for industrial conditions and operated at industrial sites.

\section{- On a Coordinated Energy/Environmental Policy}

It is recommended that the Department of Energy and the Environmental Protection Agency jointly develop a National Strategy for implementing the national policy of converting industry from oil and gas to coal. The need is for a balanced, coordinated, and long-range plan that includes consistent environmental regulations and energy initiatives. These policies lleed to include not only positive eronomic incentives that promote voluntary conversion, but also covenants that will remove many of the risks associated with the uncertainty of future regulations.

\section{- On Industry/Government Cooperation}

It is recommended that the Department of Energy undertake a number of cooperative investigations with industry on a regional basis to explore innovative solutions to the problems of converting to coal. These efforts would have a twofold purpose. They would first provide industry an opportunity to evaluate various energy options that they might not 
otherwise consider; and, secondly, they would provide a very valuable source of input for federal energy planning. The cooperative investigations could include consideration of new technologies as well as innovative institutional arrangements. As examples of the latter, the area coal terminal and central steam generation concepts are both promising. But site specific studies with industry participation are required to determine the true merits and limitations. 


\section{REFERENCES}

1. The National Energy Plan, Executive Office of the President, April 1977.

2. E. C. Fox et a1., Conversion to Coal in the Industrial Sectors - $A$ Study of the Barriers and Some Alternatives, ORNL/TM-6139 (to be published).

3. W. Dupree et al., Energy Perspectives 2, U.S. Department of the Interior (June 1976).

4. P. G. Bos et al., The Potential for Cogeneration Development in Six Major Industries by 1985, Resource Planning Associates, Cambridge, Massachusetts (September 1977).

5. Dow Chemical Company, Energy Industrial Center Study, prepared for the National Science Foundation (19/4).

6. PEDCO Environmental, Inc., EPA Industrial Boiler FGD Survey First Quarter 1978, EPA 600/7-78-052a (March 1978).

7. Coal Week 3(34) (Aug. 29, 1977).

8. Environmental Reporter, Section 50.9, p. 35 (Jan. 14, 1977).

9. R. L. Wright, Union Carbide, Victoria, Texas, personal communication with T. D. Anderson and E. C. Fox, Oak Ridge National Laboratory, May 1977.

10. Neal Collins, Environmental Standards Section, Environmental Protection Agency, personal communication with E. C. Fox, Oak Ridge National Laboratory, Apr. 27, 1978.

11. Environmental Protection Agency, National Emission Data System (NEDS), AQCR Emissions Generated Specifically for This Study. Emissions in Tons Per Year as of June 20, 1977, Research Triangle Park, North Carolina.

12. Research Triangle Park, North Carolina, Air Quality Data - 1975 Second Quarter Statistics, ERDA-450/2-76-025.

13. Hydroscience, Inc., An Assessment of Long-Distance Thermal tinergy Transport: A Comparison Between Water, Steam and Hot Oil. ORNL Subcontract No. 194-14274V (to be published).

14. Tube Express Systems, Inc., PipeZine Transportation for Solid Cargo, company brochure. 
THIS PAGE

WAS INTENTIONALLY

LEFT BLANK 
ORNL/TM-6661

Internal Distribution

1-20. T. D. Anderson

21. S. Baron

22. H. I. Bowers

23. R. C. Davis

24. R. G. Donnelly

25. M. S. Edwards

26-44. E. C. Fox

45. R. L. Graves

46. J. F. Harvey

47. R. S. Holcomb

48. J. E. Jones, Jr.

49. O. H. Klepper

50. R. E. Kuhlmann

51. M. Levenson

52. L. E. McNeese

53. J. P. Nichols
54. M. O1szewski

55. H. Postma

56. M. Rosenthal

57. G. Samuels

58. D. Scott

59. I. Spiewak

60. J. R. Tallackson

61. J. F. Thomas

62. H. E. Trammell

63. D. B. Trauger

64. ORNL Patent Office

65-66. Central Research Library

67. Document Reference Section

68-69. Laboratory Records Department

70. Laboratory Records, ORNL-RC

\section{External Distribution}

71. Director, Nuclear Research and Development Division, Department of Energy, Oak Ridge Operations office, Oak Ridge, TN 37830

72. Office of Assistant Manager, Energy Research and Development, Department of Energy, Oak Ridge Operations Office, Oak Ridge, TN 37830

73. F. E. Dearing, Department of Energy, Oak Ridge Operations Office, Oak Ridge, TN 37830

74. R. L. Aspenson, 3M Company, P.O. Box 33331, St. Pau1, MN 55133

75. J. G. Bates, Power System Engineering Inc., P.0. Box 19398, Houston, TX 77024

76. J. T. Cockburn, Celanese Chemical Co., 777 South Post Oak Road, Houston, TX 77056

77-86. Carl Di Bella, Mining and Engineering Economics, Program Control and Support Divieion, Department of Energy-FE Program, 20

Massachusetts Avenue, Washington, DC 20545

87. C. D. Ernst, Missouri Pacific Railroad Company, St. Louis, MO 63100

88. G. Fletcher, Georgia Institute of Technology, Atlanta, GA 30332

89. P. H. Gleick, 1070 Park Avenue 7-B, New York, NY 10028

90. L. R. Green, Sears Roebuck and Company, Sears Tower, Chicago, IL 60684

91. B. Groten, Texas Eastern Transmission Company, P.0. Box 2521, Houston, TX 77001

92. D. B. Henschel, U.S. Environmental Protection Agency, Research Triangle Park, NC 27711

93. C. W. Knudsen, Assistant Director, Engineering, Economics and Standards, Program Control and Support Division, Department of Energy-FE Program, 20 Massachusetts Avenue, Washington, DC 20545 
94. W. E. Longfield, Babcock \& Wilcox, 4282 Strausser Street N.W., North Canton, OH 44720

95. W. B. Marx, American Boiler Manufacturers Association, Suite 317, American Building, 1500 Wilson Boulevard, ARlington, VA 22209

96. C. L. Mason, Science Applications, Inc., 800 Oak Ridge Turnpike, P.0. Box 843, Oak Ridge, TN 37830

97. E. R. Moats, Goodyear Tire \& Rubber Company, 1144 East Market Street, Akron, OH 44311

98. C. Roach, Congressional Budget office, House Annex \#2, Room 3412A 2nd \& D Street SW, Washington, DC 20515

99. P. L. Tremont, Monsanto Company, 800 North Lindberg Boulevard, St. Louis, MO 63166

100. R. L. Wright, Union Carbide Corporation, P.0. Box 186, Port Lavaca, TX 77979

101-127. Technical Information Center, Department of Energy, Oak Ridge Operations Office, Oak Ridge, TN 37830 